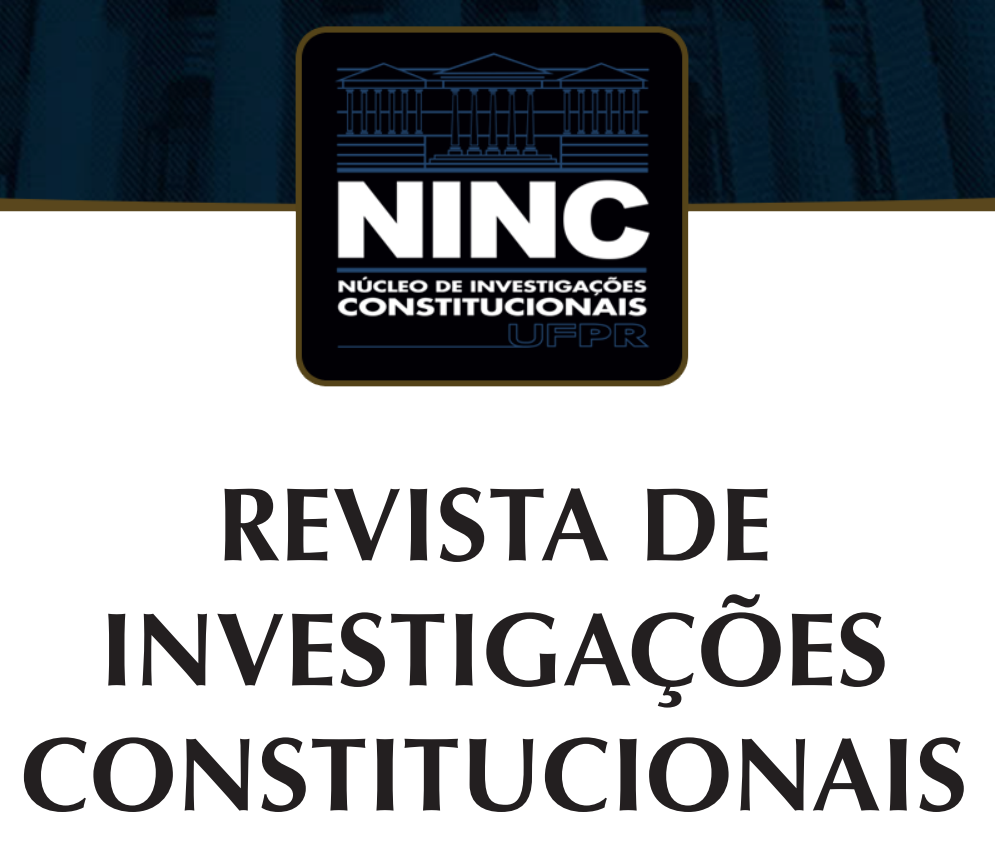

JOURNAL OF CONSTITUTIONAL RESEARCH

vol. 7 | n. 2 | maio/agosto 2020 | ISSN 2359-5639 | Periodicidade quadrimestral Curitiba | Núcleo de Investigações Constitucionais da UFPR | www.ninc.com.br 


\title{
The tension between global public procurement law and nationalist/populist tendencies: proposals for reform*
}

\author{
A tensão entre o direito global de compras públicas e as \\ tendências nacionalistas/populistas: propostas de reforma
}

\author{
JAVIER MIRANZO-DÍAZ ${ }^{1}$, 1 ,** \\ ' University of Granada (Granada, España) \\ " University of Castilla-La Mancha (Cuenca, España) \\ javier.miranzo@uclm.es \\ https://orcid.org/0000-0002-3186-2848 \\ Recebido/Received: $18.06 .2020 /$ June $18^{\text {th }}, 2020$ \\ Aprovado/Approved: 30.10 .2020 / October 30th, 2020
}

Abstract

GPA had a main objective from its very beginning: confronting discrimination between bidders on national or geographical grounds and opening the system up to greater competence between private actors. The World has experienced a gradual liberalization of public national markets that was almost perceived as a natural process. But this other time thought never-ending process is experiencing serious difficulties. The global political panorama seems to be moving again towards the once forgotten nationalist ideologies; a fact that has brought back again the old host of economic protectionism to
Resumo

O Acordo de Contratação Pública (ACP) teve um objetivo principal desde o seu início: enfrentar a discriminação entre licitantes por motivos nacionais ou geográficos e abrir o sistema para maior competência entre atores privados. O mundo experimentou uma liberalização gradual dos mercados públicos nacionais que quase foi percebida como um processo natural. Mas este processo está passando por sérias dificuldades. O panorama político global parece estar se movendo novamente em direção às ideologias nacionalistas outrora esquecidas; um fato que trouxe de volta o antigo hospedeiro do protecionismo econômico à linha de

Como citar esse artigo/How to cite this article: MIRANZO-DÍAZ, Javier. The tension between global public procurement law and nationalist/populist tendencies: proposals for reform. Revista de Investigações Constitucionais, Curitiba, vol. 7, n. 2, p. 355-400, maio/ago. 2020. DOI: 10.5380/rinc.v7i2.74570.

"This article has been prepared within the framework for I+D Administrative Law Beyond the State national plan (PGC2018101476-B-100).

"*z Professor of Administrative and Public Procurement Law at the University of Granada (Granada, España) and at the University of Castilla-La Mancha (Cuenca, España). He holds a PhD in Public procurement and two Masters in the fields Public Procurement and environmental law by the University of Castilla-La Mancha. He is Member of the Spanish Observatory for Public Procurement, and has carried out research stays in the University of Oxford and the European University Institute. He is Member of the Local Committee for Public Procurement in Cuenca (Spain), and has developed consulting activities concerning the EU coverage of the GPA, the anti-corruption system for public procurement in Mexico, or public procurement implementation projects in north Africa. E-mail: javier.miranzo@uclm.es. 
the front line of international public markets regulation. The present paper analyses the existing situation from a critical approach. Firstly, it carries out a study of the mechanisms and motives that lie behind populisms and its relationship with international law legitimacy and traditional procurement bias. Secondly, it signals the central role of GPA as the main international instrument to face neo-protectionism, and focuses on the subtle nature of most procurement barriers and how current review mechanism fail to both efficiently tackle potential infringements and to guarantee states' autonomy. Finally, a proposal for reform is made as to the functioning of the GPA review mechanisms through the creation of a mixed review system.

Keywords: public procurement; Global Administrative Law; protectionism; free trade; nationalism. frente da regulação dos mercados públicos internacionais. O presente artigo analisa a situação existente a partir de uma abordagem crítico. Em primeiro lugar, realiza-se um estudo dos mecanismos e motivos que estão por trás dos populismos e sua relação com a legitimidade do direito internacional e o viés tradicional de aquisição. Em segundo lugar, sinaliza-se o papel central do ACP como o principal instrumento internacional para enfrentar o neoprotecionismo, e se concentra na natureza sutil da maioria das barreiras de aquisição e como o mecanismo de revisão atual não consegue enfrentar eficientemente possíveis infrações e garantir a autonomia dos Estados. Por fim, faz-se uma proposta de reforma quanto ao funcionamento dos mecanismos de revisão do GPA através da criação de um sistema de revisão mista.

Palavras-chave: contratação pública; Direito Administrativo Global; protecionismo; livre comércio; nacionalismo.

\section{CONTENTS}

1. Introduction; 2. Global public procurement and the concept of the common interest; 3. Reinforced concepts of community identity: the rise of populisms; 4. Some effects of populisms in the process towards a global public procurement; 4.1. Free Trade Agreements and the crisis of TTIP; 4.2. Brexit and the EU; 4.3. The Covid-19 crisis: Temporary Instabilities or Paradigm Shift? 5. Regulatory vs Non-Regulatory Barriers In Public Procurement; 6. Addressing Non-Regulatory Barriers Under International Law; 6.1. The GPA and its oversight mechanisms; 6.2. Review mechanisms of administrative decisions in breach of international law; 7. The tension between the globalisation process and populist movements; 8. Conclusions; 9 . References.

\section{INTRODUCTION}

Over the last 70 years a gradual process of globalization has taken place at many levels of legal and economic action ${ }^{1}$. The initially economic course gave place to the creation of international bodies in charge of the safeguarding of international peace and democracy (e.g. United Nations), to foster free trade and economic cooperation (e.g. WTO) or with both economic and peacekeeping goals (EEC, EU), resulting in a steady homogenization of values, principles, freedoms and rights ${ }^{2}$. From a legal perspective, globalisation puts pressure on the harmonization of rules. After the fall of the Berlin's Wall, some scholars even adventured themselves to identify a phenomenon that they named as "the end of history"3 - which has its legal matching in the concept of the

INNERARITY, Daniel. El nuevo espacio público. Madrid: Espasa Libros, 2006, p. 224; GOLDMAN, David. Historical Aspects of Globalisation and Law. In: DAUVERGNE, Catherine (ed.). Jurisprudence for an Interconnected Globe. Aldershot: Ashgate, 2003, p. 43.

2 AUBY, Jean-Bernard. Globalisation, Law and the State. 1st ed. Oxford: Hart Publishing, 2017, p. 1-28.

3 FUKUYAMA, Francis. The end of History and the Last Man. 1st ed. London: Penguin, 2012. 
"convergence of laws"4 - acknowledged as the process of homogenization provoked by globalization in both law and ideologies, which would eventually lead to a unique and uniform international governance ${ }^{5}$. In terms of public procurement, the development of an international or global public procurement has similarly relied for its development on the liberal democracy values of international law, having the WTO and the GPA as the main engines for development ${ }^{6}$.

However, reality evidenced during the last decades how the alleged homogenization process deriving from globalization under the lead of liberal democracies is far from being conclusive. The reluctance to communist-tradition countries to surrender to the liberal western standards (Russia, Cuba, Venezuela, etc.) or the emergence of new non-democratic actors as main players of the international community (Qatar, Arab Emirates, etc.) has evidenced that international affairs still need to gather a wide variety of actors and ideologies ${ }^{7}$. From 2008 and the broke out of the economic crisis, the main threats for the conventional supranational and international institutions, standards, values and norms have come from the intensification of previously marginal nationalist and protectionist movements in the very core of western liberal democracies $^{8}$, leading to a crisis of democratic legitimation in all spheres of action ${ }^{9}$. This has resulted in a gradually increase on discriminatory interventions by states around the Globe with the aim to protect their economies ${ }^{10}$. Whether this crisis was structural or cyclical, the tendency seems to be aggravated by the Covid-19 crisis as States reactions have been directed to export and import bans with different levels of explicitly ${ }^{11}$, up to a point in which most European and occidental countries had adopted export bans. In this context, this article tries to recognize the tensions between these tendencies and global public procurement in order to identify lines of action for future developments.

\footnotetext{
4 DELMAS MARTY, Mireille. Trois défis pour un droit mondial. Paris: Le Seuil, 1997, p. 76.

5 SCHOLTE, Jan Aart. Global Civil Society. In:WOODS, Ngaire (ed.). The Political Economy of Globalization. London: Macmillan, p. 173-201, 2000.

6 CLERC, Evelyne. La mondialisation des marchés publics. BATSELÉ, Didier et al. (eds.). Les marchés publics à I'aube du XXIe siècle. Bruxelles: Bruylant, 2000, p. 145.

7 See in general CASTELLS, Manuel. The Power of Identity. $2^{\text {nd }}$ ed. Malden: Wiley-Blackwell, 1997.

8 ERIXON, Fredrik; SALLY, Razeen. Trade, Globalisation And Emerging Protectionism Since The Crisis. ECIPE Working Paper, n. 2, 2010, p. 3. Available at: <https://www.econstor.eu/bitstream/10419/174841/1/ecipe-wp-2010-02.pdf>.

9 CONSTANTINESCU, Cristina; MATTOO, Aaditya; RUTA, Michele. The Global Trade Slowdown: Cyclical or Structural?. International Monetary Found, vol. 15, n. 6, Jan. 2015. Available at: < https://www.imf.org/exter$\mathrm{nal} / \mathrm{pubs} / \mathrm{ft} / \mathrm{wp} / 2015 / \mathrm{wp} 1506 . \mathrm{pdf}>$.

10 See the database in Official documents and media reports of the Global Trade Alert team, University of St Gallen, (consulted on 20 May 2020), in which they report up to four hundred discriminatory interventions in 2019. See as well DISDIER, Anne-Célia; FONTAGNÉ, Lionel; ENXHI, Tresa. Public Procurement- Related Protection: Insights from the Global Trade Alert Database. European Commission Technical Report 2017.

11 See the examples addressed by BALDWIN, Richard E.; EVENETT, Simon J (ed.). COVID-19 and Trade Policy: Why Turning Inward Won't Work. London: Centre for Economic Policy Research, 2020.
} 
For that purpose, let us begin with the overlapping interests involved in public procurement decision-making.

\section{GLOBAL PUBLIC PROCUREMENT AND THE CONCEPT OF THE COMMON INTEREST}

When awarding a contract, there is a first goal that must be attained: the supply of services to the Administration or the citizens. There is, therefore, a main group of interested people that the contract managers must observe when setting the awarding criteria. This group can be identified with the customers of the service, which can either be the Public Administration itself or a reduced group of citizens more or less well defined. For the construction of a Hospital, for example, account must be taken of the interests of the future workers (doctors, nurses, etc.) along with those of wide groups of the population that can be potential customers of the final healthcare service. The relevance of the interests, however, becomes weaker the further a given community is from the Hospital (other cities, other countries, etc.).

However, the current public procurement goals go far beyond the mere supply of goods and services to a given group of costumers. Public procurement has become a public policy, and as such, a key tool for the development of societies in various different ways that requires, when designing the procurement criteria, the observance of broader interest that exceed those of the final users of the service provided.

It is the case for environmental protection. Procurement officers are nowadays expected to include in the procurement documents technical requirements and awarding criteria aimed to guarantee or maximize the environmental protection. These requirements are not grounded on a direct benefit for the final users of the service, but rather on an indirect and more abstract benefit for a broader group of citizens which is often referred to as the society. Similar implications derive from the use of social measures in the procurement procedures. Some of the conceivable measures, such as labour standards, respond to the interests of those involved in the provision of services (workers), but other potential social clauses -such as those related to the inclusion of disfavoured groups in the labour market through public contracts or provisions for real gender equality within a given sector- are founded on interests belonging to groups that might not be directly affected by the contract.

In terms of anti-corruption provisions, even if it can be argued that corruption actually affects each contract individually and that therefore its fight is founded on purely contractual interests, the truth is that present integrity strategies are legitimized on the fact that corruption undermines economy and democracy in a much broader 
scope than that of the contract ${ }^{12}$. This justifies that even if the public officer can prove that corruption in a given scenario can actually benefit the final users of the service, this does not legitimate his action, because there are broader extracontractual interests to protect.

Likewise, the whole modern EU and international public procurement system the emerged in the $60 \mathrm{~s}$, based on non-discrimination on grounds of nationality or geographical origin, fundamentally relies on similar widened concept of public interests. Economic theories show how greater competition in a given contract have potential benefits for the contract itself, facilitating the attainment of a best value for money ${ }^{13}$. Technologic and welfare development highly depends, thus, on physical mobility and posting of workers by the awarded companies. The application of the non-discrimination principle is based on the idea that its use would generate important benefits that would exceed the contract itself, affecting the economic system as a whole.

Finally, even though benefiting enterprises is not the main goal of public procurement, it is undoubtedly one of its effects. Given that irremediably one of the bidders is to be awarded the contract, a significant concern arises on which would be the consequences of that awarding, not to the final users and the ultimate quality of the service provision, but to the economic system in which the undertaking is imbedded, or ultimately, to the undertaking itself. Awarding the contract to a given enterprise based on a given region would undoubtedly benefit the economy of that region. And therefore, when it is found that awarding contracts to companies from a certain geographical background instead of others can have macro-economic implications, contracting authorities and public institutions are tempted to take control over which sector of the economy is going to be the ultimate beneficiary of procurement markets, leading to a natural tendency towards protectionism ${ }^{14}$. Undertakings are, at this point, one of the interests involved in the decision-making process, and who do we want to favour in a given awarding procedure plays a clear role when evaluating the public interest of the contract.

The reasons underlying non-discrimination principle are grounded on the believe that these transregional interests are, indeed, favouring a wider economic interest that would end up benefiting the economic development at a higher level, so that the

\footnotetext{
12 MIRANZO DÍAZ, Javier. Causas y efectos de la corrupción en las sociedades democráticas. Revista de la Escuela Jacobea de Posgrado, n. 14, p. 1-26, jun. 2018. Available at: <https://www.jacobea.edu.mx/revista/ numero14.php>.

13 KUTLINA-DIMITROVA, Zornitsa; LAKATOS, Csilla. The Global Costs of Protectionism. World Bank Policy Research Working Paper, Washington, n. 8277, Dec. 2017. Available at: < http://documents1.worldbank.org/ curated/en/962781513281198572/pdf/WPS8277.pdf>; BALDWIN, Richard; EVENETT, Simon (ed.). The collapse of global trade, murky protectionism and the crisis: Recommendations for the G20. Centre for Economic Policy Research (CEPR), 2009, p. 10.

14 AUBY, Jean-Bernard. Globalisation, Law and the State. 1st ed. Oxford: Hart Publishing, 2017, p. 39.
} 
principle acts here as a counterbalance to this tendency to favour local or regional economies over others ${ }^{15}$. And it does son in two different directions:

1. In scenarios in which there are strong enough senses of belonging and enforcement measures apply, principle of non-discrimination is entitled to a wider and broader common interest. Its application is grounded on the believe that it increases the total wealth of participating communities. All that is needed to mitigate possible weaknesses or unbalances is effective redistribution policies and economic interrelations between individuals in a particular region as to assume that the particular benefits for a given community emerging from the awarding of a contract to a local enterprise would eventually revert in the good of the society as a whole by means of redistribution ${ }^{16}$.

In these scenarios, the principle of non-discrimination acts as a sort of absolute rule and it is implemented by jurisdictional powers through enforcement mechanisms.

2. When the sense of togetherness is not strong enough -and therefore it has not given place to sufficiently developed institutional and democratic mechanisms-, interrelations between economies and redistribution of welfare are not clearly set. In these situations we can identify different communities or groups, and the principle of non-discrimination acts as a general inspiring rule that would only be effectively applied in the extent in which parties agree based on negotiation.

The sense of belonging and the concept of public interest will thus play a central role for the application of the principle in one way or the other. These two different scenarios are fairly well differentiated in the national sphere (institutional enforcement) and the international sphere (negotiated enforcement). But there are nowadays other less clear scenarios in which the two ways of application are closely interrelated.

\section{THE SENSE OF BELONGING: FROM PERSONAL TO NATIONAL IN- TERESTS}

When talking about national or regional preferences and the principle of non-discrimination, few people tend to think of it as related with what we call "conflicts of interest". It is clear that these situations fall normally out of the application of non-discrimination principle, but the rationale of regional preferences is in many ways not very different from that of a conflict of interest situation.

\footnotetext{
15 KUTLINA-DIMITROVA, Zornitsa. Government Procurement: Data, Trends And Protectionist Tendencies. DG Trade, issue 3, Sep. 2018, p. 5. Available at: < https://trade.ec.europa.eu/doclib/docs/2018/september/tradoc_157319.pdf>.

16 HAMADA, Koichi. Why we need globalization. The Japan Times, 2018. Available at: <https://www.japantimes.co.jp/opinion/2018/05/03/commentary/japan-commentary/why-we-need-globalization/\#.XJOTxi3FTOS>.
} 
Conflicts of interest can be provoked by an illegal incentive (bribes), appear as a result of personal interests (e.g. shareholder of one of the bidders), or emerge as a result of a third person's interest or activities (e.g. wife/husband is shareholder of one of the bidders). In this last scenario the procurement official does not necessarily expect a personal profit from a potential biased decision, but it is the closeness with the person potentially benefited which renders the situation problematic. The presence of a conflict of interest here lies on the ties or relation between two given actors.

If we explore a bit more this kind of conflicts of interests' behaviour, we find that it is quite difficult to trace a line on when two people are close enough to be held to have a conflict of interest. With regard to family ties, the approach is relatively simple as there are social formal ties between members of a family, and therefore closeness can be argued on formal terms regardless of whether there is actual relationship between two family members ${ }^{17}$. The issue at this level can come with regard to level of family ties at which the limit must be set ${ }^{18}$.

However, the appreciation of a conflict of interest becomes more problematic when the relation between two people is merely functional. If one of the procurement officers has a friendship with one of the shareholders of a particular tenderer, a risk of bias can be perceived. And yet, although friendship can be agreed to be a highly relevant social relation as to generating risk of manipulation or deviation from public interest when it is at stake, it is quite challenging to set a rule on how strong a friendship is expected to be for it to be understood as giving place to a conflict of interest.

But the key element here is that, both in family and friendship grounded conflicts of interests, the person acting on behalf of the public authority does not expect any direct profit if acting partially, but instead, the element that generates a risk of bias in the affected person is the feeling of closeness to certain individuals in society, the sense of belonging to a particular group (family, friends, etc.) ${ }^{19}$. And at this point, we

\footnotetext{
17 At this point we need highlight the objective nature of conflicts of interests, which entails that the the will of the person affected by the conflict is irrelevant when it comes to identifying a conflict of interest situation. It is therefore not necessary that the person intends to take any advantage of such an irregular situation, but instead the objective existence is sufficient. European Commission. Report from the Commission de réflexion pour la prévention des conflits d'intérêts dans La Vie Publish. Pour une nouvelle déontologie De la vie Publique. Presented to President Of the French Republic on 26 January 2011, p. 15. Available at: < https:// www.hatvp.fr/wordpress/wp-content/uploads/2016/02/Rapport-Commission-Sauve.pdf>; SOLOVEICIK, Deividas; SIMANSKIS, Karolis. The Evolving Concept of «Conflict of Interest» in the EU Public Procurement Law. European Procurement \& Public Private Partnership Law Review (EPPPL), vol. 12, issue 2, 2017, p. 114. Available at: <https://epppl.lexxion.eu/article/EPPPL/2017/2/6>; CJEU, case T-403/12, Intrasoft International v Commission 13 October 2015, para 75; CJEU, case T-415/10, Nexans France v Entreprise commune Fusion for Energy, of 20 March 2013, para 115.

18 MIRANZO DÍAZ, Javier. Hacia la configuración de una estrategia eficiente de integridad en la contratación pública. Madrid: Marcial Pons, 2020, p. 74.

19 "Any gathering, club, or association can be 'democratic' in its participatory procedures of decision making and in some manifestation of a minimal egalitarian ethos of mutual recognition of all those involved. We can say of a family, classroom or firm that they are 'democratic'. But such an understanding of democracy tends to be
} 
can think of multiple other social groups that can pose a risk for the impartiality of a given procurement officer. If two people share leisure activities such as belonging to a religious society or fraternity, going together to the gym, taking their kids to the same school, and the like, it is likely for them to generate a greater grade of empathy for those people in comparison with the rest of the society. These situations do not seem to engender a risk as high as the previous ones, but if a person if left to decide which person to favour from a variety of individuals, he or she would probably be prone to choose the closest one to his/her social circle.

In certain African countries, for example, we can identify the existence of socio-ethnic groups which play a great role in the public procurement decision-making process, and being part of the ethnic majority that governs public procurement entails greater chances of having access to government contracts ${ }^{20}$.

Following this line of reasoning, geographical senses of belonging also play ultimately a great role in human decision-making and can affect the outcome of a public decision. Peoples tend to identify themselves with a particular local, regional and national community, and in some cases, bigger social or cultural communities such as Latin-American, American, European, African, etc. ${ }^{21}$ These constructions of the concept of us and the human tendency to favour those individuals belonging to the community instead of others is, in broad terms, what principle of non-discrimination aims to put an end to.

All the above-mentioned individuals and their particular interests (relatives, friends, religious, ethnic groups, etc.) are indeed part of the public interest and should be weighed when evaluating the pros and cons of a given procurement project as part of the public interest ${ }^{22}$. A biased decision emerges, thus, when one of those interests involved (e.g. those of a family member) is overweighed with relation to the other

\footnotetext{
procedural and applicable to societies in their various incarnations". CHENEVAL, Francis and NICOLAIDIS, Kalypso. The social construction of democracy in the European Union. European Journal of Political Theory, vol. 16, issue 2, 2016, p. 238. Available at: < https://journals.sagepub.com/doi/abs/10.1177/1474885116654696>.

20 The study uses data from 474 public procurement staff to demonstrate that social identity, ethical egoistic, legislative, amoral, and religious moral schemas account for $78.51 \%$ of the variance in moral schema of respondents. All these schemas were found to be significant predictors, accounting for $73.3 \%$ of public procurement corruption" [..] "Those service providers (suppliers) who are considered non-members of the favored socio-ethnic groups do not benefit much from the bidding, evaluation and contract awards". MPEERA NTAYI, Joseph; NGOBOKA, Pascal; SABIITI KAKOOZA, Cornelia. Moral Schemas and Corruption in Ugandan Public Procurement. Journal of Business Ethics, vol. 112, issue 3, p. 417-436, 2013. Available at: <https://link.springer. com/article/10.1007/s10551-012-1269-7>.

21 This reality of dispersed power and identities can be appreciated specially in federal countries. See MAIR, Peter. The europeanization dimensión. Journal of European Public Policy, vol. 11, issue 2, p. 337-348, 2004.

22 About the evolution of the concept of public interest towards a pluralism of private interests, see MORISON, John, and GORDON, Anthony. The Place of Public Interest. In: GORDON, Anthony; AUBY, Jean-Bernard; MORISON, John; ZWART, Tom (eds.). Values in Global Administrative Law. London: Hart Publishing, p. 215238, 2015.
} 
interests involved to a point that it ends up playing a central role in a final decision, which appears clearly unbalanced.

In the case of familiar ties, friendship and other ethnic, religious or ideological aspects, the crucial fact is that they are neither legitimate nor relevant values by themselves as to be regarded as individually measurable in a procurement procedure. They are nor related to the subject matter of the contract, and being part of the family or of a given ethnic group does not provide any particular benefit for the final outcome apart from the individualized profit that a potential awarding of the contract can create on the given family or social group. Favouring these particular social communities is not accepted as a legitimate goal in public procurement - they are only to be favoured in the extent in which they are part of a greater public interest. If they are directly or indirectly favoured in grounds of family ties, friendship, religion, ideology, ethnic, or any other social community construction, they will be in breach of the principle of non-discrimination, resulting in biased decisions.

However, the exposed reasoning acquires a different nuance when a given social community is indeed politically represented and therefore the protection of its interests is legally attributed to public institutions acting on their behalf ${ }^{23}$. At each one of the political levels, that is, spheres for democratic representation of interests geographically delimited by a voting system, there is a risk that these local interests will conflict with the greater general interest ${ }^{24}$. Like in the cases described in previous paragraphs, local interests respond to the construction of a social community that has a particular sense of belonging, which in some cases can give place to situations where there is a temptation to favour local enterprises over foreigners.

In structures in which there is sufficient consistency of a legal community representing a broader interest than the local ones, there is a system of institutional balance and distribution of powers between different political levels within the same territory that guarantees the homogeneous strategy on procurement law ${ }^{25}$. The challenge of procurement authorities and officers at this point is to persistently integrate their interests from a local, a national and a European perspective. This entails a logic of positive sum game where solutions found might require giving up something today in the expectation of payback tomorrow, or scarifying some apparently direct benefits for narrower groups of interests for the sake of a higher cause. In other words, at this level

\footnotetext{
23 "questions of political authority as opposed to non-political institutions such as tea parties, tango dancing, and the like". CHENEVAL, Francis; NICOLAIDIS, Kalypso. The social construction of democracy in the European Union. European Journal of Political Theory, vol. 16, issue 2, 2017, p. 237. Available at: < https://journals. sagepub.com/doi/abs/10.1177/1474885116654696>

24 CASTELLS, Manuel. The Power of Identity. $2^{\text {nd }}$ ed. Malden: Wiley-Blackwell, 1997, p. 71-166.

25 FERRAJOLI, Luigi. Poderes Salvajes: la crisis de la democracia constitucional. Madrid: Trotta, 2013, p. 45.
} 
non-discrimination is guaranteed through institutionally driven trust, diffuse reciprocity and the sense of belonging to a community of overlapping interests ${ }^{26}$.

The consideration of non-discrimination principle as one of the basic concepts of any modern procurement legal system engenders prominence conferred to the broadest - or highest - social community or ethos legitimated by law that can successfully enforce non-discrimination - i.e. the European Union ${ }^{27}$. This generally leads in public procurement to the prohibition of criteria that can generate favouritism grounded on any other lower or narrower constructions of social communities or networks ${ }^{28}$.

But at international level the sense of belonging is still weak, and the relations between nations are still seen as that of differentiated individuals with different and competing interests. This questions even the existence of a common interest -upon which principle of non-discrimination relies-, and therefore the feasibility of the assumption of shared responsibility for the decisions and norms enacted by that community ${ }^{29}$.

Additionally, the powers of international bodies are blurred, and so are the mechanisms of enforcement ${ }^{30}$. This results in an international law primarily based on bilateral relations and voluntary obligations, which do not provide for strong enforceability systems when crisis arise. At this level there is not a supra-national authority with sufficient power as to ban any discriminatory practices (setting aside the EU), but rather a dispersed institutional and regulatory framework with clear enforcement mechanis$\mathrm{ms}^{31}$. Far from the idyllic global democracy longed by many ${ }^{32}$, in which the world's civil

\footnotetext{
26 TAGIURI, Giacomo. EU law and national belonging: Appeasing insiders while Resisting Nationalisms. Revue trimestrielle de droit européen, n. 4, Dalloz, 2018, p. 743. Available at: <https://www.researchgate.net/publication/342833586_The_tension_between_global_public_procurement_law_and_nationalistpopulist_tendencies_proposals_for_reform>.

27 HERNÁNDEZ GONZÁLEZ, José Ignacio. El contrato administrativo en el derecho administrativo global: Una perspectiva Iberoamericana. In: ALCARAZ, Hubert; VERGARA BLANCO, Alejandro (dir.). Itinerario latinoamericano del derecho público francés. Tirant Lo Blanch, p. 367-382, 2019; HERNÁNDEZ GONZÁLEZ, José Ignacio. Las prerrogativas de la administración en los contratos de las administraciones públicas en Iberoamérica. In: RODRÍGUEZ-ARANA, Jaime (dir.); MORANDINI, Federico; FERNÁNDEZ CARBALLAL, Almudena (coord.). Contrataciones públicas en el marco de los derechos sociales fundamentales. Madrid: Instituto Nacional de Administración Pública, p. 67-100, 2017.

28 This is indeed the founding goal of the EU primary intervention in public procurement issues in the 70 s. MORENO MOLINA, José Antonio. El nuevo Derecho de la Contratación Pública de la Unión Europea: directivas 4.0. Oxford: Chartridge Books Oxford, 2015, p. 30.

29 MORISON, John; GORDON Anthony. The Place of Public Interest. In: GORDON, Anthony; AUBY, Jean-Bernard; MORISON, John; ZWART, Tom (eds.). Values in Global Administrative Law. London: Hart Publishing, p. 215-238, 2011.

30 AUBY, Jean-Bernard. Globalisation, Law and the State. Oxford: Hart Publishing, 2017, p. 72.

31 AUBY, Jean-Bernard. Globalisation, Law and the State. Oxford: Hart Publishing, 2017, p. 70; WALKER, Neil. Populism and Constitutional Tension. University of Edinburgh School of Law Research Paper, vol. 18, n. 18. Available at: < https://papers.ssrn.com/sol3/papers.cfm?abstract_id=3182359>.

32 FUKUYAMA, Francis. The end of History and the Last Man. $1^{\text {st }}$ ed. London: Penguin, 2012; see also SCHOLTE, Jan Aart. Global Civil Society. In: WOODS, Ngaire (ed), The Political Economy of Globalization. London and New York: Macmillan, p. 173-201, 2000.
} 
society will triumph over the egotism of the nation state ${ }^{33}$, the international community and the idea of globalisation is -still-constructed under the notion of national sovereignty ${ }^{34}$, which means that the content and the extent of the non-discriminatory principle needs to be negotiated and agreed on a consensus based on reciprocity, relying on soft enforcement mechanisms exposed to regulatory risks. The ultimate foundation of non-discrimination principles over a sense of belonging to a particular social community fades away at international level ${ }^{35}$, and this leaves the content of international non-discrimination principle specially exposed to political powers, namely populisms. In current times, sovereignty is argued to be conceived "as a relational resource rather than a sphere of autonomy"36, in which one of the necessary premises for it to work is the principle of positive comity from states or principle of affirmative cooperation between government agencies of different nations ${ }^{37}$.

Populisms, however, exhort the absolute and sacred autonomy of national willpower, rejecting collaborative or pluralist concepts of sovereignty, challenging the institutional balance.

\section{REINFORCED CONCEPTS OF COMMUNITY IDENTITY: THE RISE OF POPULISMS}

Populist movements generally meet certain common features that make them a threat to globalization, regardless of their left or right-wing ideology ${ }^{38}$. They all hold anti-system or anti-establishment ideas, and, either because of the extoling of national identity or as a consequence of the yearn for social protection mechanisms, populisms irremediably fear globalization as one of the main threatens for the welfare state. It is argued to move away the decision-making process from people ${ }^{39}$ and consequently, they present rather protectionist characteristics on their trade ideological programs

33 See the thoughts of AUBY, Jean-Bernard. Globalisation, Law and the State. Oxford: Hart Publishing, 2017, p. 1-28.

34 SASSEN, Saskia. A Sociology of Globalization. New York: W.W. Norton \& Company, 2007; see as well the primary critics of CERNY, Philip G. Globalization and the End of Democracy. European Journal of Political Research, vol. 36, issue 1, 1999.

35 PICARD, Gabriel B. Legality and legitimacy in global administrative law. e-Pública, vol. II, n. 3, p. 215-229, dez. 2015. Available at: <https://www.e-publica.pt/volumes/v2n3/pdf/Vol.2-N\%C2\%BA3-Art.14.pdf>.

36 AUBY, Jean-Bernard. Globalisation, Law and the State. Oxford: Hart Publishing, 2017, p. 106.

37 CRAIG, Paul. Shared Administration and Networks: Global and EU Perspectives. In: GORDON, Anthony; AUBY, Jean-Bernard; MORISON, John; ZWART, Tom (eds.). Values in Global Administrative Law. London: Hart Publishing, p. 81-116, 2011.

38 TAGIURI, Giacomo. EU law and national belonging: Appeasing insiders while Resisting Nationalisms. Revue trimestrielle de droit européen, n. 4, 2018, p. 743. Available at: < https://www.researchgate.net/publication/342833586_The_tension_between_global_public_procurement_law_and_nationalistpopulist_tendencies_proposals_for_reform >.

39 GAMBLE, Andrew. Globalization and the New Populism. PATRICK, Diamond (ed.) The crisis of globalization: democracy, capitalism and inequality in the twenty-first century. London: IB Tauris, 2019, p. 85. 
trying to shield the interests of what they call "people"40. And this is done by constructing a new narrative over the identity of the people for which they tend to present an oversimplified vision of reality that harks back to a bygone era -which indeed might have never existed ${ }^{41}$.

Some scholars have pointed out that new populism is seen to be drawing its strength from those left behind by globalization within the Western World ${ }^{42}$. There were already concerns on the potential negative effects of liberalization on certain underdeveloped nations, but up till now there was no actual awareness of the possible long term effects of globalization varying from different social levels within the same country ${ }^{43}$, leading to a feeling of the existence of free riders among levels of the population and provoking a greater divide between urban or metropolitan spaces and the rural areas - or those who are connected to the sources of globalization and those who are $\operatorname{not}^{44}$.

According to some scholars, the expansion of the ethos and consequently of the concept of public interest on which globalisation is founded frequently entails hurting a substantial part of a participating communities, at least in the short run ${ }^{45}$. In this sense, the revolt against globalization can be argued to respond to a failure of the States to compensate the losers of globalization ${ }^{46}$.

However, populisms or nationalisms cannot be explained solely on economic grounds. Instead, some of their roots are strongly engrained in culture and democratic

40 WALKER, Neil. Populism and Constitutional Tension. University of Edinburgh School of Law Research Paper, vol. 18, n. 18, 2018. Available at: < https://papers.ssrn.com/sol3/papers.cfm?abstract_id=3182359>.

41 PATRICK, Diamond. The Great Globalization Disruption: Democracy, Capitalism and Inequality in the Industrial World. PATRICK, Diamond (ed.) The crisis of globalization: democracy, capitalism and inequality in the twenty-first century. London: IB Tauris, 2019, p. 31.

42 GAMBLE, Andrew. Globalization and the New Populism. PATRICK, Diamond (ed.) The crisis of globalization: democracy, capitalism and inequality in the twenty-first century. London: IB Tauris, 2019, p. 90.

43 COTTIER, Thomas. Trade Policy in the Age of Populism: Why the New Bilateralism Will Not Work. Brexit: The International Legal Implications, n. 12, 2018, p. 4. Available at: <https://www.cigionline.org/publications/ trade-policy-age-populism-why-new-bilateralism-will-not-work>.

44 PATRICK, Diamond. The Great Globalization Disruption: Democracy, Capitalism and Inequality in the Industrial World. PATRICK, Diamond (ed.) The crisis of globalization: democracy, capitalism and inequality in the twenty-first century. London: IB Tauris, 2019, p. 31; FRIEDEN, Jeffry A. The Backlash Against Globalization and the Future of the International Economic Order. PATRICK, Diamond (ed.). The crisis of globalization: democracy, capitalism and inequality in the twenty-first century. London: IB Tauris, 2019, p. 133.

45 GIDRON, Noam; HALL, Peter A. Populism as a Problem of Social Integration. Comparative Political Studies, vol. 53, n. 7, p. 1027-1059. Available at: <https://journals.sagepub.com/doi/abs/10.1177/0010414019879947>; HAMADA, Koichi. A Better Approach to Globalization. Yale Global Online, 2018. Available at: <https://yaleglobal.yale.edu/content/better-approach-globalization>.

46 KALDOR, Mary. Nationalism and Globalisation. Nations and Nationalism, vol. 10, n. 1-2, 2004, p. 161-177, Available at: <https://onlinelibrary.wiley.com/doi/10.1111/j.1354-5078.2004.00161.x>;WALKER, Neil. Populism and Constitutional Tension. University of Edinburgh School of Law Research Paper, vol. 18, n. 18, 2018. Available at: < https://papers.ssrn.com/sol3/papers.cfm?abstract_id=3182359>. 
legitimacy ${ }^{47}$. Far from the potential detrimental effects of the phenomenon, a re-emergence of local or territorial identity has been identified as interlinked with globalisation ${ }^{48}$.

Populism typically claim the lack of legitimacy of some given institutional layers -claimed as external- which impose a set of basic rules, principles or limits that affect them. And for that, it constructs a new narrative of democratic legitimacy grounded on cultural aspects. Populism is widely characterized as a new way of approaching the us and they dichotomy mentioned supra, as they generate new and stronger narratives on who we are and why we are not them ${ }^{49}$. They reinforce certain senses of belonging as opposed to other social or geographical communities which are not part of the group and which differ sufficiently from us as to be categorized as them, and which should be set aside in the decision-making process - immigrants, establishment oligarchs, politi$\mathrm{CS}$, or the international community ${ }^{50}$. And therefore, as there are two different realities, two different selves, the relations between them would have to be constructed over negotiation, because in our decisions, we would only take into account their interest to the extent in which that may represent an eventual benefit for us.

This can either apply to the elites (left wing populisms) or to the migrants (right wing populisms $)^{51}$, or to higher and broader levels of decision-making to the central government -i.e. Catalan nationalism constantly claims lack of legitimacy of the Spanish State on a variety of issues affecting the "Catalan peoples" 52 - to the EU - i.e. Brexit, Front National, La Lega Norte, etc.-, or to the United Nations and international organisations - i.e. Trump Administration aggressiveness towards the international community. They key aspect is that, whichever layer populisms is targeting as its enemy, they are not us

47 COX, Michael. The Rise of Populism and the Crisis of Globalisation. Irish Studies in International Affairs, vol. 28, p. 9-17, 2017. Available at: <http://eprints.Ise.ac.uk/86880/7/Cox_Rise\%20of\%20populism\%20published_2018.pdf>.

48 As Auby points out, "in a globalising world which appears to attach importance only to functional identities, individuals are rediscovering a taste for their territorial identities". AUBY, Jean-Bernard. Globalisation, Law and the State. Oxford: Hart Publishing, 2017, p. 106.

49 RODI, Patricia. Populist Political Communication Going Mainstream? The Influence of Populist Parties on Centre-Left Parties in Western Europe. PATRICK, Diamond (ed.) The crisis of globalization: democracy, capitalism and inequality in the twenty-first century. London: IB Tauris, 2019, p. 164.

50 TAGIURI, Giacomo. EU law and national belonging: Appeasing insiders while Resisting Nationalisms. Revue trimestrielle de droit européen, n. 4, Dalloz, 2018, p. 743. Available at: <https://www.researchgate.net/publication/342833586_The_tension_between_global_public_procurement_law_and_nationalistpopulist_tendencies_proposals_for_reform $>$.

51 TAGIURI, Giacomo. EU law and national belonging: Appeasing insiders while Resisting Nationalisms. Revue trimestrielle de droit européen, n. 4, Dalloz, 2018, p. 743. Available at: <https://www.researchgate.net/publication/342833586_The_tension_between_global_public_procurement_law_and_nationalistpopulist_tendencies_proposals_for_reform $>$.

52 As an example, Spanish Constitution states that only the State is legitimated to undertake diplomatic representation in other countries, but Catalan nationalists argue a lack of democratic legitimacy of the State to represent the Catalan peoples in any aspect of life. CASTELLS, Manuel. The Power of Identity. $2^{\text {nd }}$ ed. Malden: Wiley-Blackwell, 1997, p. 45. 
and have nothing to do with $u s^{53}$. Populism takes only one of the multiple us that conform human nature and makes it the only significant one for decision making process, or at least it provides it with a greater weigh in the final decision ${ }^{54}$. That is, it relies on the democratic essence of one of the politically legitimated collective groups or "us" and reinforces its identity as to an absolute "us" that is alleged to be absolute sovereign of the future of the peoples ${ }^{55}$. This approach rejects, of course, the enforcement or intervention capacity of any other level of decision making, as it would be an unlawful interference on the will of the community, and consequently legitimates unilateral decisions of withdrawal or the unilateral creation of new paths or ways of actions by a particular level of decision-making. This phenomenon has been referred to as "negative transnational solidarity" ${ }^{156}$, and its rationale contrasts with the intrinsic nature of the non-discrimination principle mentioned supra, which engenders a necessary openness for the sake of wider interests with smother or inexistent direct benefits for a given narrower community.

Populisms try, in sum, to disregard the fact that he superior political status enjoyed by a group of citizens referred to as demos does not require that this demos act alone as a self-sufficient decision-making entity ${ }^{57}$. Decisions at any political or administrative level are not taken merely on behalf of those that a given public institution is directly representing, and therefore there are always conceivable constrains that might come from peripheral actors ${ }^{58}$. The construction of any multi-level structure of

53 WALKER, Neil. Populism and Constitutional Tension. University of Edinburgh School of Law Research Paper, vol. 18, n. 18, 2018. Available at: < https://papers.ssrn.com/sol3/papers.cfm?abstract_id=3182359>.

54 See, for example, how national identities maximisation has represented a risk for EU integration in which Carey has cleverly named the problem of "undivided loyalties". CAREY, Sean. Undivided Loyalties: is national identity an Obstacle to European integration?. European Union Politics, vol. 3, issue 4, p. 387-413, 2002. Available at: <https://journals.sagepub.com/doi/10.1177/1465116502003004001>.

55 RODI, Patricia. Populist Political Communication Going Mainstream? The Influence of Populist Parties on Centre-Left Parties in Western Europe. PATRICK, Diamond (ed.) The crisis of globalization: democracy, capitalism and inequality in the twenty-first century. London: IB Tauris, 2019, p. 167.

56 WALKER, Neil. Populism and Constitutional Tension. University of Edinburgh School of Law Research Paper, vol. 18, n. 18, 2018. Available at: <https://papers.ssrn.com/sol3/papers.cfm?abstract_id=3182359>.

57 ORTEGA, Luis. Global Citizenship and Global Legitimacy. GORDON, Anthony; AUBY, Jean-Bernard; MORISON, John; ZWART, Tom (eds.). Values in Global Administrative Law. London: Hart Publishing, p. 251-262, 2011.

58 As Nicolaidis has explained: "persons with status can differ with regard to the thick or thin bundle of competencies they hold. For instance the owner of a car might only be allowed to drive at $30 \mathrm{mph}$ on certain streets and still be the owner of the car. Similarly, the sovereign can be bound by legal and political constraints or disabilities that keep him from making certain laws and still be the sovereign law-maker". CHENEVAL, Francis; NICOLAIDIS, Kalypso. The social construction of democracy in the European Union. European Journal of Political Theory, vol. 16, issue 2, 2017, p. 238. Available at: <https://journals.sagepub.com/doi/ abs/10.1177/1474885116654696>. 
power ${ }^{59}$ requires clear and consistent connections between the different levels of such structures ${ }^{60}$.

\section{SOME EFFECTS OF POPULISMS IN THE PROCESS TOWARDS A GLOBAL PUBLIC PROCUREMENT}

The most common reaction of governments before a scenario of economic crisis and uncertainty is a withdrawal from international or foreign interests in benefit of the welfare our own administrated citizens. This, of course, is not possible in local or other sub-national level, or at least is not as easy to make it part of the public discourse and the public procurement agenda, let alone putting it into practice. The strong institutional counterbalancing previously mentioned in this work acts here as a deterrent that hinders unilateral and exclusive lines of activity. However, even if there should ideally be some measures for coordination of the measures of withdrawal or protection in times of crisis, when it comes to transnational relations there are no effective counterbalances and the "wild powers" of politics can turn the official discourse around"1.

\subsection{Free Trade Agreements and the crisis of TTIP}

The TTIP was aimed at trying to overcome trade barriers of public procurement and provide benefits for both EU and the US amounting to more than 10 billion euros ${ }^{62}$. However, in just over a year since the start of negotiations, the United States and the European Union went from an association agreement that was to lay "the foundations of 21st century trade" to a threat of a full-blown tariff war grounded on the populist discourse of national security ${ }^{63}$. This provoked that from the very first stages, there were important differences and difficulties in the negotiations between both parties ${ }^{64}$.

59 LINARELLI, John. Global procurement law in times of crisis: new buy American policies and options in the WTO system. In: ARROWSMITH, S. and ANDERSON, R.D. The WTO Regime on Government Procurement: Challenge and Reform. Cambridge: Cambridge University Press, p. 773-802, 2011.

60 ORTEGA, Luis. Global Citizenship and Global Legitimacy. GORDON, Anthony; AUBY, Jean-Bernard; MORISON, John; ZWART, Tom (eds.). Values in Global Administrative Law. London: Hart Publishing, p. 251-262, 2011.

61 LINARELLI, John. Global procurement law in times of crisis: new buy American policies and options in the WTO system. In: ARROWSMITH, S.; ANDERSON, R. D. The WTO Regime on Government Procurement: Challenge and Reform. Cambridge: Cambridge University Press, 2011, p. 791.

62 ECORYS. Non-Tariff Measures in EU-U.S. Trade and Investment - An Economic Analysis. Report prepared for the European Commission, 2009.

63 HAYES, Eric. TTIP: transatlantic free trade at last?. Global Affairs, vol. 1, n. 2, p. 113-120, 2015. Available at: <https://www.tandfonline.com/doi/abs/10.1080/23340460.2015.1012914>.

64 DEZSŐ ZIEGLER, Tamás. TTIP and Its Public Criticism: Anti-Globalist Populism versus Valid Dangers. Studies in International Economics, 2016, vol. 2, n. 2, p. 19-51. Available at: <https://papers.ssrn.com/sol3/papers. cfm?abstract_id=2930039>. 
One of the main EU concerns regarding procurement under the TTIP was that a large share of procuring entities within US states, including - and especially - regional and local entities, were not covered by the GPA ${ }^{65}$. This, however, created a competency issue in the US as the federal Government could only foster sub-federal entities by indirect measures ${ }^{66}$. The necessity for the US, in order to meet the requests set out by the EU, to use the grants system as a way of indirect harmonization of procurement in the federated states were some of the central issues that the negotiations of the TTIP raised ${ }^{67}$

On the EU side, the necessity to change the EU debarment rules to comply with the US requirements created and initial restraint. Furthermore, over the last years there has been in Europe a increasing debate on the limits of the exclusiveness of the international trade competencies transferred by Lisbon Treaty ${ }^{68}$ and a rising concern about the risk that the liberalisation of trade markets can pose to environmental protection, public health standards, labour law and social standards, etc ${ }^{69}$. The US sought to ease the bureaucratic burdens related to social, technical and environmental requirements required by the EU, which create de facto barriers of access - they have been referred to as sophisticated protectionism practices ${ }^{70}-$. This kind of protectionism based on social protection has been strongly fed by left-wing parties, which have been the main opponents to TTIP and procurement negotiations.

Consequently, the EU sought to soften local protectionism in the EU but was not eager (or at least was under considerable pressure of some MEPs not to be) to relax the environmental or social requirements in exchange. When the rise of populisms in each side of the Atlantic took place, the result was unsurprisingly a radicalisation of both protectionists tendencies. Nowadays, not just the TTIP negotiations are frozen ${ }^{71}$,

65 AYMERICH CANO, Carlos. La contratación pública en el TTIP. R.V.A.P., vol. I, n. 117, 2017, p. 19-41.

66 WOOLCOCK, Steve; HEILMAN GRIER, Jean. Public Procurement in the Transatlantic Trade and Investment Partnership Negotiations. Paper No. 2 in the CEPS-CTR project "TTIP in the Balance" and CEPS Special Report No. 100, 2015. Available at: <https://www.ceps.eu/system/files/SR100PublicProcurementandTTIP.pdf>.

67 YUKINS, Christopher R. The European Procurement Directives and The Transatlantic Trade \& Investment Partnership (TTIP): Advancing U.S. - European Trade and Cooperation in Procurement. GWU Law School Public Law Research Paper, n. 2014-15, 2014. Available at: < https://papers.ssrn.com/sol3/papers.cfm?abstract_ id=2433219>; YUKINS, Christopher. Breaking The Impasse In The Transatlantic Trade And Investment Partnership (TTIP) Negotiations: Rethinking Priorities In Procurement. The Government Contractor, vol. 56, n. 27, 2014. Available at: < https://papers.ssrn.com/sol3/papers.cfm?abstract_id=2471653>.

68 AYMERICH CANO, Carlos. La contratación pública en el TTIP. R.V.A.P., vol. I, n. 117, 2017, p. 19-41

69 See the AK Position Paper EU Trade and Investment Agreements TTIP and CETA, 2015, available at <https:// www.arbeiterkammer.at/infopool/akportal/Positionspapier_TTIP_CETA_english_new.pdf>.

70 GÓRSKI, Jędrzej. Public Procurement in 21 st Century: Balancing Liberalisation, Social Values and Protectionism. Thesis Submitted in Partial Fulfilment of the Requirements for the Degree of Doctor of Philosophy in Laws, The Chinese University of Hong Kong July 2016, p. 36.

71 COTTIER, Thomas. Trade Policy in the Age of Populism: Why the New Bilateralism Will Not Work. Brexit: The International Legal Implications, n. 12, 2018, p. 8. Available at: <https://www.cigionline.org/publications/ trade-policy-age-populism-why-new-bilateralism-will-not-work>. 
and the debate has gone a step forward within the US as to to whether the US should quit the GPA 72 .

Anyway, unsurprisingly, new negotiations on TTIP excluded any public procurement issue from the potential agreement ${ }^{73}$. As public procurement probably is one of the subjects from the agreement in which the exercise of public power is more evident, parties wanted to make sure that they should not have any constraint if they want to foster their enterprises before the others. This essentially leaves EU-US procurement relations to be supervised under the rules of the GPA.

\subsection{Brexit and the EU}

Other strongly identity-related issue affecting public procurement has been Brexit. There is undoubtedly a sense of belonging in Brexit ${ }^{74}$, for regardless of the economic or welfare matters, the foundations of Brexit lie on the fact that there is little or none self-identification of the British as Europeans ${ }^{75}$. The personal narrative of British individuals does not regularly include European references ${ }^{76}$, and they do not want to make sacrifices in benefit of EU because EU means they.

The stable dimension of EU transmission of sovereignty powers seems to play here a crucial role. Lord Bridge in one of the decisions handed down by the House of Lords expressed that "whatever limitation of its sovereignty Parliament accepted when it enacted the European Communities Act 1972 was entirely voluntary"77, and therefore it could be entirely revoked or amended at any time on any decision. Brexit does not

\footnotetext{
72 YUKINS, Christopher. Withdrawing the United States from the WTO Government Procurement Agreement (GPA): Assessing Potential Damage to the U.S. and Its Contracting Community. The Government Contractor, vol. 62, n. 6, 2020, p. 35. Available at: < https://scholarship.law.gwu.edu/cgi/viewcontent.cgi?article=2735\&context=faculty_publications>; CERNAT, Lucian; KUTLINA-DIMITROVA, Zornitsa. Why public procurement openness is more important now than ever. CEPR Policy Portal, 16 april 2020. Available at: <https://voxeu. org/article/why-public-procurement-openness-more-important-now-ever>.

73 "Joint U.S.-EU Statement following President Juncker's visit to the White House", 2018, available at: http:// europa.eu/rapid/press-release_STATEMENT-18-4687_en.htm ; and "EU-U.S. Trade Talks: European Commission presents draft negotiating mandates", 2018, available at: http://europa.eu/rapid/press-release_IP-19-502_ en.htm ; A. Gardner. "Prospects for a Transatlantic Trade Deal”, 2019, available at: https://www.brunswickgroup. com/prospects-for-a-transatlantic-trade-deal-i9640/

74 DAMASIO, Antonio, R. Self Comes to Mind: Constructing the Conscious Brain. London: Pantheon, 2010; WALKER, Neil. Populism and Constitutional Tension. University of Edinburgh School of Law Research Paper, vol. 18, n. 18, 2018. Available at: < https://papers.ssrn.com/sol3/papers.cfm?abstract_id=3182359>.

75 TSOUKALIS, Loukas. Brexit and Globalization: Collateral Damage or an Accident Waiting to Happen?. PATRICK, Diamond (ed.). The crisis of globalization: democracy, capitalism and inequality in the twenty-first century. London: IB Tauris, 2019, p. 275.

76 DALY, Paul. Reprendre le contrôle: ennuis et ironies (The Ironies of 'Taking Back Control'). Legal Studies Research Paper Series, n. 38, 2018. Available at: <https://papers.ssrn.com/sol3/papers.cfm?abstract_ $\mathrm{id}=3162560$ > .

77 CRAIG, Paul. The Impact of Community Law on Public Law. In: LEYLANDS, Peter and WOODS, Terry Administrative Law Facing the Future: Old Constraints and New Horizons. Oxford: Blackstone, 1999, p. 27.
} 
seek the isolation of the the country, but a relation grounded in different, more negotiated-based relations ${ }^{78}$.

The apparent contradiction between the initial enthusiasm for the UK self-determination in procurement, which would set them free from EU procurement imposed rules, and the subsequent eagerness with which the UK Government announced the approval for the UK accession to GPA the thought provoking title of "support for UK's continued access to $£ 1.3$ trillion market" (emphasis added) ${ }^{79}$, is indeed grounded on the strictly voluntary, and therefore temporary, nature of the sovereignty transmission. It implies a paradigm shift in the application of the international procurement law principles: from enforcement to negotiation after Brexit. Brexit discourse is based on the proclamation that the EU, even though can be said to represent an unstable institutional arrangement, has become too stable and too binding when it comes to UK citizens spirits $^{80}$. This is why the UK, at the same time, repudiates EU stability and embraces more unstable institutional arrangements such as the GPA.

The withdrawal agreement of Brexit does not include any provision related to trade or procurement, and it requires the UK to adhere to EU rules until the transition period ends ${ }^{81}$. After these transition period, only UK rules will apply, but, as has been pointed out, as the UK has already transposed to national legislation most of the EU procurement rules, in practice not much will change until it is expressly changed ${ }^{82}$. Whether the populist drifting rudderless observed in the UK will lead the Government to take buy-British policy and the eventual intensity of such measures, that is another question. But in any case, in a no-deal scenario regarding a future FTA, EU remaining legislation could be revocable at any time. The GPA will be consequently the cornerstone of transnational procurement in Britain, and the UK will have more freedom to

\footnotetext{
78 Not in vain Paul Craig accurately entitled its Act 7 about Brexit "In Search of a Negotiating Strategy". See CRAIG, Paul. Brexit, A Drama: The Interregnum. Yearbook of European Law, vol. 36, n. 1, p. 3-45, 2017. Available at: <https://academic.oup.com/yel/article/doi/10.1093/yel/yex005/4562542>.

79 See the notice at https://www.gov.uk/government/news/support-for-uks-continued-access-to-13-trillion-market.

80 MENDEZ, Mario; MENDEZ, Fernando; TRIGA, Vasiliki. Direct Democracy in the European Union: How comparative federalism can help us understand the interplay of direct democracy and European integration. Revista de Ciencia Política, vol. 29, n. 1, 2009, p. 57-83. Available at: < https://scielo.conicyt.cl/scielo.php?scrip$\mathrm{t}=\mathrm{sci}$ abstract\&pid=S0718-090X2009000100003\&lng=en\&nrm=iso >.

81 DUFFY-MEUNIER, Aurélie. Réflexions de nature constitutionnelle sur la loi sur le retrait du Royaume-Uni de I'Union européenne, I'European Union (Withdrawal) Act 2018. Revue trimestrielle de droit européen, vol. 64, n. 4, 2018, p. 759-781.

82 DALY, Paul. Reprendre le contrôle: ennuis et ironies (The Ironies of 'Taking Back Control'). Legal Studies Research Paper Series, n. 38, 2018. Available at: <https://papers.ssrn.com/sol3/papers.cfm?abstract_ id $=3162560$ >.
} 
re-negotiate the way in which the principle of non-discrimination is applied in its government procurement system ${ }^{83}$.

\subsection{The Covid-19 crisis: Temporary Instabilities or Paradigm Shift?}

The pandemic has evidenced the interdependency of States in supply of public procurement related goods. But as mentioned before, populisms and nationalisms of diverse natures seem to have evolved on different ways throughout the last decade, and as the protectionist tendency grows, the Covid-19 crisis can generate a turning point. Emergency powers in democratic States are aimed at preventing a potential chaotic situation in which multiple identities and collective institutions within the country might be tempted to obviate wider interests in shake of those if the smaller community. In times of crisis, thus, emergency powers are meant to virtually sacrifice every other sense of collectivity to concentrate the power in the fundamental and primary "us": the nation. This, of course, has an effect on inner collectivities (see complaints in Catalunya, Spain $\left.{ }^{84}\right)$, but it has an even greater effect on the weak international "global interest". It sacrifices every shared interest, taking a step back to a purely utilitarian use of international relations ${ }^{85}$. Emergency situations, therefore, help to reinforce the concentrated identity in the state as unified and separated from others ${ }^{86}$.

This international situation has resulted in trade barriers to avoid shortage of basic or health-related goods in multiple countries ${ }^{87}$, which in its turn provoked scarcity of those goods in importing countries. The politic narrative of national reindustrialization has vigorously emerged, and the possible use of public procurement measures to foster national enterprises -in order to foster the strengthening of the internal chain of production - a has appeared as an evident consequence ${ }^{88}$. Consequently, some scholars have foresee the proliferation of "trade and investment barriers and technological decoupling, with a central role reserved for states rather than for international

\footnotetext{
83 CRAIG, Paul. Brexit, A Drama: The Interregnum. Yearbook of European Law, vol. 36, n. 1, p. 3-45, 2017. Available at: <https://academic.oup.com/yel/article/doi/10.1093/yel/yex005/4562542>

84 See, for example, the article COVID-19: El Govern ve innecesario desplegar el ejército en Catalunya: "Que los destinen a otros territorios", 19th March in La Vanguardia: https://www.lavanguardia.com/politica/20200319/474257623774/govern-ejercito-cataluna-innecesario-coronavirus.html

85 See for example Kissinger approach of international relations as described in FUKUYAMA, Francis. The end of History and the Last Man. 1st ed. London: Penguin, 2012, p. 321.

86 Most decisions in Covid-19 procurement, however, have been taken in the export side, and not in the import side, and as public procurement rules is mainly affected by import issues, there has been no great direct effects.

87 HOEKMAN, Bernard; FIORINI, Matteo; YILDIRIM, Aydin. COVID-19: Export controls and international cooperation. In: BALDWIN, Richard E. and EVENETT, Simon J. COVID-19 and Trade Policy: Why Turning Inward Won't Work. London: Centre for Economic Policy Research, p. 63-76, 2020.

88 JAMES, Harold. A Pandemic of Deglobalization?. Project Syndicate, $28^{\text {th }}$ February 2020.
} 
institutions" 189 . In our opinion, regardless of the long-term persistency of the effects of the pandemic, it is clear that in the short run it will reinforce identarian protectionisms. Procurement might be seen in the near future as a tool for fostering national industries -requiring or promoting national providers over international, and will foster further revolts against the binding or semi-binding nature of international institutions ${ }^{90}$.

\section{REGULATORY VS NON-REGULATORY BARRIERS IN PUBLIC PRO- CUREMENT}

Current barriers to public procurement go far beyond traditional tariff barriers ${ }^{91}$. In its webpage ${ }^{92}$ the European Commission highlights some of the trade barriers that one can encounter if bidding in some third countries. As an example, we can see that Argentina applies price preferences for domestic goods in public procurement; Australia, has not adopted non-discrimination as a key principle and maintain discriminatory measures; in Brazil, foreign companies must be legally established in Brazil to take part in national tenders, and a preference for domestic goods and services of up to $25 \%$; in China there is an aggressive buy-Chinese policy which, in principle, allows only Chinese companies to bid in public tenders; foreign bids are allowed as exceptions. All these examples impose some national preference or quota that explicitly limits the access for foreign companies to government procurement. They are examples are, so to speak, of straight regulatory or de jure barriers.

But possible barriers might be less visible, indirect measures, such as bureaucracy requirements. In Chile, for example, the process for getting on the registry for public contracts is overly bureaucratic. Obstacles include obtaining recognition of academic qualifications for workers, the need to produce numerous notarized documents (e.g., certificates of good conduct of workers, certification of previous projects) and obtain a local tax identification number ${ }^{93}$. In Israel, English notices of international tenders are only published in hard-copy in Israeli English newspapers and are not available online.

89 GRUSZCZYNSKI, Lukasz. The COVID-19 Pandemic and International Trade: Temporary Turbulence or Paradigm Shift?. European Journal of Risk Regulation, vol. 11, n. 2, p. 337-342, 2020. Available at: <https://papers. ssrn.com/sol3/papers.cfm?abstract_id=3669017>.

90 See, as an example, the analysis of President Trump's reaction against the WTO in HUDSON, Josh, DAWSEY, J.; MEKHENNET, Souad. Trump expands battle with WHO far beyond aid suspension. The Washington Post, $26^{\text {th }}$ April 2020.

91 Its presence is residual even in strategically protected markets such as defence. SCHOENI, Daniel E. On the Non-tariff Barriers Obstructing Free Trade in the Transatlantic Defense Procurement Market. In: RACCA, Gabriela; YUKINS, Christopher (eds.). Joint Public Procurement and Innovation: Lessons Across Borders. Brussels: Brulyant, p. 419-470, 2019.

92 See: https://madb.europa.eu/madb//barriers_result.htm?isSps=false\&sectors=5\&measures=110.

93 DÍAZ BRAVO, Enrique; RODRÍGUEZ LETELIER, Aníbal. Contratos administrativos en Chile. Santiago de Chile: RIL Editores, 2016. 
The EU is not itself free of some protectionist tendencies over the last years, either with explicit or subtle initiatives. Regarding the first type, we can appreciate them in some official documents such as opinion of the European Committee of the Regions (ECR) Strengthening territorial resilience: empowering regions and cities to face globalization, in which the ECR proposed that voluntary, "non- binding initiative within the EU along the lines of a 'Buy from European Regions Charter', supporting high-quality local and regional products in Europe should be considered" in order to support local and regional products in Europe ${ }^{94}$. Likewise, in terms of public procurement, the Opinion of the ECR The CAP after 2020 calls for a review of European law on the award of public contracts in the mass catering sector, "incorporating a locality clause for food supply"

But these still are, stricto sensu, regulatory barriers - even if we can call them "soft" or fuzzy regulatory barriers. Beyond this, however, a range of contractual content requirements might be included in an explicit or concealed manner in concessions, public works and other contracts, and these requirements might not explicitly imply a breach of the GPA or a bilateral treaty signed by a Contracting State. In the EU context, even if article 25 of the Directive 2014/24/EU requires for international bidders under GPA or other treaties a "no less favourable than the treatment accorded to the works, supplies, services and economic operators of the Union", in practice this equal treatment is merely formal ${ }^{96}$. There is, however, a material side of the principle of non-discrimination which requires taking measures as to guarantee that every bidder has "effective" equal access to procurement, which is not being guaranteed by the $\mathrm{EU}^{97}$.

The example of Israel publication of notices only in hard copy format is quite illustrative. Even if it provides formal equal treatment, as anybody could physically go and check the notice, it creates in practice a great burden for international enterprises. There is a similar barrier in the EU guarantee-based approach to environmental, social or quality standards, for even if formally they are open to anyone, it is de facto impossible - or extremely costly - for many foreign enterprises to comply with them. With regard to this, we have already pointed out how US main concerns regarding TTIP

94 Opinion of the European Committee of the Regions - Strengthening territorial resilience: empowering regions and cities to face globalization (2018/C 054/07).

95 Opinion of the European Committee of the Regions - The CAP after 2020, (2017/C 342/02).

96 In 2013 , only about $0.5 \%$ of the awarded contracts covered by the Directives were awarded to third countries companies, and this low rate is alleged to respond mainly to the difficulty of fulfilling the quality standards stipulated in the Public Procurement Directives, specific to the European community. PîRVU, Daniela; BÂLDAN, Cristina. Access to the EU Public Procurement Market: Are There Disparities Based on the Origin of Economic Operators?. Journal of Economic Issues, vol. XLVII, n. 3, p. 765-780, 2013. Available at: <https://www.tandfonline. com/doi/ref/10.2753/JEl0021-3624470309?scroll=top>; similar conclusions are reached by CARBONI, Chiara; IOSSA, Elisabetta; MATTERA, Gianpiero. Barriers to Public Procurement: A Review and Recent Patterns in the EU.

Working Paper IEFE - The Center for Research on Energy and Environmental, 92, 2017, p. 4.

97 GERAPETRITIS, George. Affirmative Action: A New Challenge for Equality. In: GORDON, Anthony; AUBY, Jean-Bernard; MORISON, John; ZWART, Tom (eds.). Values in Global Administrative Law. London: Hart Publishing, p. 263-296, 2011. 
were linked to the "excessive" and overly bureaucratic standardization of qualifications required by EU law which render highly difficult for foreign undertakings to bid; but the barriers become even worse when it comes to undertakings coming from third world or developing countries ${ }^{98}$. There is of course an ethical dilemma with the liberalisation of these practices which evidences the contradictions engendered by globalisation ${ }^{99}$, as it would require some degree of a waiver of the proudly achieved environmental or social guarantees of EU procurement. A scenario that might indeed promote the increase of populism ${ }^{100}$.

In this context, the EU seems to have opted for what we can call "ethical or principled protectionism", and the European Commission seems indeed to be hardening its discourse on this matter. In its Communication: Guidance on the participation of third country bidders and goods in the EU procurement market it states that some international treaties, which include the lessening of environmental requirements to third county firms, create disadvantages for EU undertakings, and therefore it calls for a need to apply the EU public procurement rules and foster environmental, social and quality standards in contracts, "as to ensure that the same, or equivalent, standards and requirements apply to EU and third country bidders"101. Similar tendencies can be observed on the social sphere, the inclusion of decent working conditions often gives place to discriminatory provisions and trade barriers with negative impacts on the openness of the market $^{102}$.

Finally, we must be aware that government procurement is not isolated from other branches of international trade. International norms such as the General Agreement on Trade in Services and General Agreement on Trade in Services (GATS) and the General Agreement on Tariffs and Trade (GATT) recognize the regulatory independence of public procurement, which is contained as one of the exclusions for their application. ${ }^{103}$ However, GPA effectiveness strongly depends, in practice, of these two

98 PÎRVU, Daniela; BÂLDAN, Cristina. Access to the EU Public Procurement Market: Are There Disparities Based on the Origin of Economic Operators?. Journal of Economic Issues, vol. XLVII, n. 3, p. 765-780, 2013. Available at: < https://www.tandfonline.com/doi/ref/10.2753/JEI0021-3624470309?scroll=top>.

99 AUBY, Jean-Bernard. Globalisation, Law and the State. Oxford: Hart Publishing, 2017, p. 1-28.

100 COTTIER, Thomas. Trade Policy in the Age of Populism: Why the New Bilateralism Will Not Work. Brexit: The International Legal Implications, n. 12, 2018, p. 3. Available at: <https://www.cigionline.org/publications/ trade-policy-age-populism-why-new-bilateralism-will-not-work>.

101 European Commission. Communication: Guidance on the participation of third country bidders and goods in the EU procurement market, 2019.

102 CORVAGLIA, Ana Maria. Public Procurement and Labour Rights: Towards Coherence in International Instruments of Procurement Regulation. Studies in International Trade and Investment Law. Oxford: Hart Publishing, 2017.

103 ANDERSON, Robert D.; MULLER, Ana C. The revised WTO Agreement on Government Procurement (GPA): Key Design Features and Significance for Global Trade and Development. Georgetown Journal of International Law, 48, 2017, p. 984. Available at: <https://www.law.georgetown.edu/international-law-journal/wp-content/uploads/sites/21/2018/05/48-4-The-Revised-WTO-Agreement-on-Government-Procurement-GPA.pdf>. 
norms. ${ }^{104}$ Whereas its provisions autonomously regulate a certain market sector, their effectiveness is directly conditioned by the measures contained in GATS and GATT as they set enabling conditions for undertakings to operate in a given territory ${ }^{105}$. Proof of this is that there has been GATT based case-law affecting or ruling over public procurement matters, such as the GATT Panel Report, Panel on Value-Added Tax and Threshold, GPR/21, adopted 16 May 1984, BISD 31S/247, concerning United States and the European Community about the validity of the exclusion of VAT when determining the estimated value of public contracts ${ }^{106}$. Therefore, effective openness of the procurement market relies on the ability to bid (GPA) and the general conditions in which competitiveness for goods and service supplying takes place (GATS and GATT) -and therefore, so does protectionism ${ }^{107}$.

\section{ADDRESSING NON-REGULATORY BARRIERS UNDER INTERNA- TIONAL LAW}

Most of the nowadays barriers to access to public procurement markets are then grounded on administrative requirements designed at internal level. Certain provisions, regardless of whether they were initially conceived for that purpose or not intentionally intended to do so, represent technical barriers to transatlantic trade. The observed nationalist tendencies could lead to a concealed regression over protectionist practices in public procurement without evidently breaching the international legal order ${ }^{108}$, and therefore review mechanisms should shift attention, in our view, from regulatory to administrative decision when it comes to public procurement ${ }^{109}$.

104 CARBONI, Chiara; IOSSA, Elisabetta; MATTERA, Gianpiero. Barriers to Public Procurement: A Review and Recent Patterns in the EU. Working Paper IEFE - The Center for Research on Energy and Environmental, 92, 2017, p. 4.

105 DAVIES, Arwel. The Evolving GPA. Lessons of Experience and Prospects for the Future. In: GEORGOPULOS, Aris C; HOEKMAN, Bernard; MAVROIDIS, Petros C. (eds.). The Internationalization of Government Procurement Regulation. Oxford Scholarship Online: 2017, p. 23.

106 AUBY, Jean-Bernard. Globalisation, Law and the State. Oxford: Hart Publishing, 2017, p. 45. The relation between these two international norms nevertheless not clear, as it can be appreciated in WT/DS412/AB/R, Canada - Certain Measures Affecting the Renewable Energy Generation Sector; WT/DS426/AB/R, Canada Measures Relating to the Feed-In Tariff Programme, adopted May 24, 2013, regarding the applicability of the government procurement exception to a particular case.

107 ANDERSON, Robert D; MULLER, Ana C. The revised WTO Agreement on Government Procurement (GPA): Key Design Features and Significance for Global Trade and Development. Georgetown Journal of International Law, 48, 2017, p. 977. Available at: <https://www.law.georgetown.edu/international-law-journal/wp-content/uploads/sites/21/2018/05/48-4-The-Revised-WTO-Agreement-on-Government-Procurement-GPA.pdf>..

108 AZOULAI, Loïc; RITLENG, Dominique. Intégration européene et passions nsationales. Revue trimestrielle de droit européen, n. 4, 2018, p.721.

109 The same line of action has been proposed by SCHWARTZ, Joshua I. Procurement in times of crisis: lessons from US government procurement in three episodes of crisis in the twenty-first century. In: ARROWSMITH, S.; ANDERSON, Robert D (eds.). The WTO Regime on Government Procurement: Challenge and Reform. Cambridge: Cambridge University Press, 2011. pp. 773-802. 
A control over this kind of discrimination based solely on preceding -either substantive or procedural- obligations and merely positive approaches falls short for the effectiveness sought. Most of these neo-protectionist tendencies are manifesting themselves as administrative decisions that transcend the formality of the positive law.

The case of administrative barriers allowed in CETA are a good example. In this treaty, signing states can introduce higher environmental requirements without breaching the agreement. CETA does not, however, explicitly mention the applicability of social criteria in public procurement. It is not clear whether they are absolute exceptions or to which extent they can be applied, and the acceptance of any exception of this kind without standardized judicial review over proportionality and reasonableness can indeed expose these guarantees for being used as indirect means for local protection.

When the legal standards at stake are homogenised in a given region (e.g. EU) the requirement of this particular level of compliance does not represent a threat for non-discrimination principles. However, non-discrimination concerns arise when the standards required are unreasonably raised as to exclude an important part of the market. In cases in which the standards at stake substantially vary from one region to the other, being geographically disconnected, the risk of use of these requirements as a concealed mean for keeping foreign companies out of the tendering procedure increases.

As several scholars have pointed out, the concept of global administrative law is not constructed up on a solid constitutional legitimacy, but its legitimacy and robustness instead rely on common values or principles such as transparency, accountability, and notably, the effectiveness of the mechanism for review ${ }^{110}$. Effective judicial assessment acts as the main factor for guaranteeing homogeneous applicability of normative content and for defining the shape of procurement principles ${ }^{111}$. Otherwise, the principles in which public international procurement law relies, which are not elaborated in detail within the GPA or the treaties, will remain open for speculation as to how the particular administrative law principles should be interpreted in detail ${ }^{112}$.

\footnotetext{
110 KINGSBURY, Benedict, KRISCH, Nico; STEWART, Richard, The Emergence of Global Administrative Law. Law and Contemporary Problems, vol. 68, n. 15, 2005; GORDON, Anthony; AUBY, Jean-Bernard; MORISON, John; ZWART, Tom. Values in Global Administrative Law: Introduction to the Collection. In: GORDON, Anthony; AUBY, Jean-Bernard; MORISON, John; ZWART, Tom (eds.). Values in Global Administrative Law. London: Hart Publishing, p. 1-16, 2011; CASSESSE, Sabino. Il diritto globale. Torino: Einaudi, 2009, p. 166; SCHMIDT-AßMANN, Eberhard. Principles of an International Order of Information. In: GORDON, Anthony; AUBY, Jean-Bernard; MORISON, John; ZWART, Tom (eds.). Values in Global Administrative Law. London: Hart Publishing, p. 117-124, 2011; TRIPATHI, Rajeshwar. Concept of Global Administrative Law: An Overview. India Quarterly, vol. 67, issue 4, p. 355-372, 2011. Available at: <https://journals.sagepub.com/doi/abs/10.1177/097492841106700405>.

111 ZWART, Tom. Would International Courts be Able to Fill the Accountability Gap at the Global Level? In: GORDON, Anthony; AUBY, Jean-Bernard; MORISON, John; ZWART, Tom (eds.). Values in Global Administrative Law. London: Hart Publishing, p. 193-214, 2011.

112 CRAIG, Paul. UK, EU and Global Administrative Law: Foundations and Challenges. Cambridge: Cambridge University Press, 2015, p. 712; ANDERSON, Robert D.; ARROWSMITH, Sue. The WTO regime on government
} 


\subsection{The GPA and its oversight mechanisms}

The GPA is the main international binding document regarding public procurement regulation ${ }^{113}$. Its main goal is to ensure the international openness of public markets, and thus, it proclaims a principle of non-discrimination - tough its content differs from that of the EU in intensity ${ }^{114}$. The GPA requires the ban of discrimination on grounds or origin of the undertaking (foreign affiliation or ownership), and based on the origin of goods and services (article IV.2). It sets and reinforce good governance, due process and integrity aspects in the procurement procedure ${ }^{115}$.

However, it can be affirmed that the practical effects of GPA have been somehow limited ${ }^{116}$. Coverage, enforceability and intensity of application is grounded on criteria such as the type of contract, its amount, the contracting entity, etc., and these criteria in their turn vary from country to country. For this purpose, each two years, members of the GPA provide list of entities covered by the Annexes of the GPA ${ }^{117}$, with possible partial revocability or modification of the coverage of provisions of the GPA grounded on reciprocity between States ${ }^{118}$. Additionally, the most favoured nation principle, valid in bilateral relations, needs to be respected ${ }^{119}$.

Also the effect of possible applicability outside thresholds is quite limited. Compared to the EU procurement directives, whose principles of public procurement apply

procurement: past, present and future. In: ARROWSMITH, Sue and ANDERSON, Robert D. The WTO Regime on Government Procurement: Challenge and Reform. Cambridge: Cambridge University Press, 2011, p. 3; RODRÍGUEZ-ARANA MUÑOZ, Jaime. The principles of the global law of public procurement. A\&C - Revista de Direito Administrativo \& Constitucional, Belo Horizonte, ano 16, n. 65, p. 13-37, jul./set. 2016.

113 DAVIES, Arwel. The Evolving GPA. Lessons of Experience and Prospects for the Future. In: GEORGOPULOS, Aris C; HOEKMAN, Bernard; MAVROIDIS, Petros C. (eds.). The Internationalization of Government Procurement Regulation. Oxford Scholarship Online: March 2017, p. 23.

114 CORVAGLIA, Maria Anna. TTIP Negotiations and Public Procurement: A Federalist Approach. Journal World Investment and Trade, vol. 19, n. 3, p. 392-414, 2017. Available at: <https://papers.ssrn.com/sol3/papers. cfm?abstract_id=2958136>.

115 ANDERSON, Robert D.; MULLER, Ana C. The revised WTO Agreement on Government Procurement (GPA): Key Design Features and Significance for Global Trade and Development. Georgetown Journal of International Law, 48, 2017, p. 993. Available at: <https://www.law.georgetown.edu/international-law-journal/wp-content/ uploads/sites/21/2018/05/48-4-The-Revised-WTO-Agreement-on-Government-Procurement-GPA.pdf>.

116 CARBONI, Chiara; IOSSA, Elisabetta; MATTERA, Gianpiero. Barriers to Public Procurement: A Review and Recent Patterns in the EU. Working Paper IEFE - The Center for Research on Energy and Environmental, 92, 2017, p. 8.

117 DAWAR, Kamala. The Government Procurement Agreement, the Most-Favored Nation Principle, and Regional Trade Agreements. In: GEORGOPULOS, Aris C; HOEKMAN, Bernard; MAVROIDIS, Petros C (eds.). The Internationalization of Government Procurement Regulation. Oxford Scholarship Online: March 2017, p. 111.

118 The State that starts a modification can even make the modifications with an objection from another GPA Party, but it would have to accept equivalent withdrawals from the objecting Party.

119 DAWAR, Kamala. The Government Procurement Agreement, the Most-Favored Nation Principle, and Regional Trade Agreements. In: GEORGOPULOS, Aris C; HOEKMAN, Bernard; MAVROIDIS, Petros C (eds.). The Internationalization of Government Procurement Regulation. Oxford Scholarship Online: March 2017, p. 113. 
to every tender within EU territory regardless of the thresholds ${ }^{120}$, the GPA is quite more flexible for not covered contracts ${ }^{121}$, leaving total discretion for countries to implement national or regional preferences ${ }^{122}$.

There is, therefore, wide flexibility for GPA parties for design market access commitments even within the GPA, and non-discrimination principle becomes conditional ${ }^{123}$. In this context, the principle of non-discrimination can take multiple shapes, and coordination of such a principle to be established in practice needs effective control over the content. However, there is a weak or soft review process when national review mechanisms fail to consistently apply the principles and provisions of the GPA ${ }^{124}$.

There are essentially two enforcement or review mechanisms within the GPA: (1) article XX, which refers to the standard WTO Dispute Settlement process through the appellate body, and which provides for government-to-government dispute settlement ${ }^{125}$; and (2) article XVIII, which requires acceding parties to have "domestic review procedures". There has been, however, little use of the former, whereas material effectiveness of the latter is virtually not possible to check if the State-State instrument is not successfully used for that purpose. ${ }^{126}$ The GPA's requirement for domestic review procedures has made an important contribution to secure formal access to justice in procurement, but effective supervision of compliance with GPA provisions is not guaranteed ${ }^{127}$.

120 MORENO MOLINA, José Antonio. Derecho Global de la Contratación Pública. Ciudad de México: Ubijus, 2011, p. 64; RODRÍGUEZ-ARANA MUÑOZ, Jaime. La Directiva Europea de Contratación Pública y la lucha contra la corrupción. Revista de Direito Econômico e Socioambiental, Curitiba, v. 8, n. 1, p. 24-56, jan/abr. 2017.

121 ANDERSON, Robert D.; MULLER, Ana C. The revised WTO Agreement on Government Procurement (GPA): Key Design Features and Significance for Global Trade and Development. Georgetown Journal of International Law, 48, 2017, p. 984. Available at: <https://www.law.georgetown.edu/international-law-journal/wp-content/uploads/sites/21/2018/05/48-4-The-Revised-WTO-Agreement-on-Government-Procurement-GPA. pdf>; ARROWSMITH, Sue. The Revised Agreement on Government Procurement: Changes to the Procedural Rules and Other Transparency Provisions. In: ARROWSMITH, Sue; ANDERSON, Robert D. The WTO Regime on Government Procurement: Challenge and Reform, Cambridge: Cambridge University Press, 2011.

122 The USA have already adopted national preference rules in the Buy American Act, creating two legal levels notably unalike one another within the same legal system.

123 ANDERSON, Robert D.; MULLER, Ana C. The revised WTO Agreement on Government Procurement (GPA): Key Design Features and Significance for Global Trade and Development. Georgetown Journal of International Law, 48, 2017, p. 985. Available at: <https://www.law.georgetown.edu/international-law-journal/wp-content/uploads/sites/21/2018/05/48-4-The-Revised-WTO-Agreement-on-Government-Procurement-GPA.pdf>.

124 DAVIES, Arwel. The Evolving GPA. Lessons of Experience and Prospects for the Future. In: GEORGOPULOS, Aris C; HOEKMAN, Bernard; MAVROIDIS, Petros C. (eds.). The Internationalization of Government Procurement Regulation. Oxford Scholarship Online: March 2017, p. 23.

125 ZWART, Tom. Would International Courts be Able to Fill the Accountability Gap at the Global Level?. In: GORDON, Anthony; AUBY, Jean-Bernard; MORISON, John; ZWART, Tom (eds.). Values in Global Administrative Law. London: Hart Publishing, p. 193-214, 2011.

126 DAVIES, Arwel. The Evolving GPA. Lessons of Experience and Prospects for the Future. In: GEORGOPULOS, Aris C; HOEKMAN, Bernard; MAVROIDIS, Petros C. (eds.). The Internationalization of Government Procurement Regulation. Oxford Scholarship Online: 2017, p. 28.

127 DAVIES, Arwel. The Evolving GPA. Lessons of Experience and Prospects for the Future. In: GEORGOPULOS, Aris C; HOEKMAN, Bernard; MAVROIDIS, Petros C. (eds.). The Internationalization of Government 
Proof of the scarce efficacy of such as system is that, since the GPA - then "Tokyo Round Code on Government Procurement" - was originally approved in 1979 only one procurement case has reached a final decision under the WTO's dispute procedures stemming from the Government Procurement Agreement ${ }^{128}$. As Gordon has pointed out, this can respond to two causes: first, procedures are relatively slow, and procurements by their nature need a dynamic pace; and second, the real party in interest may well not be the government, but rather the injured tenderer, who often would prefer to pursue its own case, without dealing with its government ${ }^{129}$.

At national level, putting Spain as an example, there have neither been cases before the procurement courts in which the GPA has been used as ground for discussion over the content of the dispute. The resolutions are made, conversely, relying essentially on national or EU case-law.

In sum, the GPA review system does not provide with real tools for homogenised interpretations of discriminatory behaviours. As there is not practical use of State claims and national courts cannot either raise questions or seek clarification, there is not a harmonised legal interpretation on how non-discrimination principle is to be interpreted under the scope of the GPA. Consequently, national courts will keep a tendency to apply these concepts as they were formerly applied in their particular legal systems.

But ironically, in the current context of uncertainty regarding the process of globalization of public procurement law, the role of GPA as a guarantor of minimum free trade and non-discrimination principles in procurement appears to be capital ${ }^{130}$, as Brexit and the failure of TTIP leave GPA as the main legislative piece in the field. In this context, the creation of a GPA permanent court has been claimed as a suitable amendment as to help to solve these shortcomings. However, it is not clear whether the GPA as an international multilateral agreement has the required demos or community basis for guaranteeing long-standing roots and proper enforcement. Let us analyse the feasibility of this proposition by examining the results of other existing dispute resolution mechanisms.

\footnotetext{
Procurement Regulation. Oxford Scholarship Online: 2017, p. 26.

128 The case of US vs Korea WT/DS163/7, 6 November 2000. YUKINS, Christopher. US Government Contracting in the Context of Global Public Procurement. In: GEORGOPULOS, Aris C; HOEKMAN, Bernard; MAVROIDIS, Petros C (eds). The Internationalization of Government Procurement Regulation. Oxford Scholarship Online: p. 265-287, 2017.

129 GORDON, Daniel I. GPA Institutional Provisions: Domestic Review Procedures \& WTO Dispute Settlement. Symposium on the revised WTO agreement on government procurement. Geneva, September 2015. Available at: < https://www.wto.org/english/tratop_e/gproc_e/symp092015_e/S7-2Gordon.pdf>.

130 WOLFE, Robert. Exposing governments swimming naked in the COVID-19 crisis with trade policy transparency (and why WTO reform matters more than ever). In: BALDWIN, Richard E.; EVENETT, Simon J (eds.). COVID-19 and Trade Policy: Why Turning Inward Won't Work. London: Centre for Economic Policy Research, p. 165-178, 2020.
} 


\subsection{Review mechanisms of administrative decisions in breach of in- ternational law}

Initial negotiations over the TTIP provided for an independent system of dispute resolution protecting foreign bidders based on the Investor-State Dispute Settlement $(\text { ISDS })^{131}$. This kind of dispute settlement resolution typically refers either to arbitration mechanisms under the International Centre for the Settlement of Investment Disputes (ICSID) or the United Nations Commission for International Trade Law Rules (UNCITRAL) administered by the Permanent Court of Arbitration (PCA), or an ad hoc tribunal ${ }^{132}$. Un any case, arbitrators, with either private or public backgrounds and with no particular judge career requirements, are elected under certain rules for a specific case with assured flexibility to the parties to agree ${ }^{133}$.

These mechanisms ensure procedural guarantees by giving a direct access to independent review bodies with competence to evaluate the decisions of a sovereign national legislator. To ensure enforceability, article 54 of the ICSID convention requires each "Contracting State" to recognize and enforce the awards of the arbitration as a judgement coming from the highest supreme or federal court of the country ${ }^{134}$.

This kind of judicial review, even though it has been widely applied in other FTA $^{135}$, rises a certain concern in terms of legitimacy of these ad hoc courts ${ }^{136}$. They are essentially used to safeguard investors' interests when signing agreement with countries whose national judiciary system does not give strong confidence. But it is done at the stake of scarifying a portion of national sovereignty, for even though arbitrary decisions do not formally imply any breach of the exclusive competences of national courts to interpret domestic legislation - see Opinion 1/17 Of The CJEU (Full Court), 30 April

\footnotetext{
131 YUKINS, Christopher. Breaking The Impasse In The Transatlantic Trade And Investment Partnership (TTIP) Negotiations: Rethinking Priorities In Procurement. The Government Contractor, vol. 56, n. 27, 2014. Available at: < https://papers.ssrn.com/sol3/papers.cfm?abstract_id=2471653>.

132 CHARRIS-BENEDETTI, Juan Pablo. The proposed Investment Court System: does it really solve the problems?. Revista Derecho del Estado, n. 42, p. 83-115, 2019. Available at: < https://revistas.uexternado.edu.co/ index.php/derest/article/view/5665>.

133 Parties can choose the Rules applicable to the disagreement, the arbitrators, the institution that is going to supervise the proceedings or the language of the proceedings. CHARRIS-BENEDETTI, Juan Pablo. The proposed Investment Court System: does it really solve the problems?. Revista Derecho del Estado, n. 42, 2019, p. 83-115, 2019. Available at: < https://revistas.uexternado.edu.co/index.php/derest/article/view/5665>.

134 HERNÁNDEZ GONZÁLEZ, José Ignacio. El control de la Administración Pública a través del arbitraje internacional de inversiones. BARNÉS, Javier. (coord.) Entre tribunales: libro homenaje a Pablo García Manzano. Madrid: Marcial Pons, 2018, p. 250.

135 KOETH, Wolfgang. Can the Investment Court System (ICS) save TTIP and CETA?. European Institute of Public Administration working paper 2016/W/01. Available: < https://www.eipa.eu/wp-content/uploads/2017/11/20161019072755_Workingpaper2016_W_01.pdf>.

136 HERNÁNDEZ GONZÁLEZ, José Ignacio. El control de la Administración Pública a través del arbitraje internacional de inversiones. Barnés, Javier. (coord.) Entre tribunales: libro homenaje a Pablo García Manzano. Madrid: Marcial Pons, 2018, p. 250.
} 
2019, on the adequacy of CETA's dispute settlement mechanism to EU Law - it implies in practice abridges of national courts on the interpretation of specific cases whose decisions can be reviewed. And this displacement is done in favour of a court that does not respond to traditional democratic standards.

Therefore, it is primary grounded on distrust from investors - and the countries behind them- on the effectiveness of national review systems, and for its application requires a sacrifice of some of the basic constitutional and democratic principles of traditional electoral mechanisms and division of powers.

As a consequence, concerns regarding ISDS have arisen in past years specially grounded on three main inadequacies: lack of consistency - leading to contradictory decisions in apparently similar cases ${ }^{137}$-, lack of impartiality ${ }^{138}$, and lack of transparen$\mathrm{cy}^{139}$, privately appointed judges with no democratic roots ${ }^{140}$. These deficiencies are particularly reluctantly tolerated in international spheres, where judicial review of legislative or administrative acts come from a level of ethos that does not represent a demos - i.e. sovereignty.

Common proposals for amendment of the system include the creation of appellate bodies ${ }^{141}$, but the EU seems to have taken another path. EU had to deal with complex concerns regarding national sovereignty and supranational powers in the past throughout the process of European integration ${ }^{142}$, so it tried to address this issue within the context of the TTIP negotiation by proposing the creation of an Investment Curt System (ICS) that would simultaneously allow to have a functional investment protection service and avoid the undermining of the rule of law. As opposed to privately appointed judges and opaque nominating procedures governing ISDS, the ICS

137 See the example of CME Czech Republic B.V. v. Czech Republic, Ad hoc - UNCITRAL Arbitration Rules, Partial Award of 13 September 2001, Final Award of 14 March 2003; and Lauder v. Czech Republic, Final Award, 3 September 2001, Ad hoc - UNCITRAL Arbitration Rules; as commented by LAIRD, Ian; ASKEW, Rebecca. Finality versus Consistency: Does Investor State Arbitration Need an Appellate System?. The Journal of Appellate Practice and Process, vol. 7, issue 2, 2005, p. 299. Available at: <https://lawrepository.ualr.edu/cgi/viewcontent.cgi?article $=1328 \&$ context=appellatepracticeprocess $>$.

138 The risks cover the conflicts of interests or double-hat dilemma -multiple roles by the same players-, the possible incentives for arbitrators to foster litigation, etc. HORVATH, Gunter J.; BERZERO, Roberta. Arbitrator and Counsel: The Double-Hat Dilemma. Transnational Dispute Management (TDM). 2017.

139 Traditionally ISDS cases were only public with the agreement of both sides, a lack of transparency which made concern about this review mechanisms grow. CHARRIS-BENEDETTI, Juan Pablo. The proposed Investment Court System: does it really solve the problems?. Revista Derecho del Estado, n. 42, p. 83-115, 2019. Available at: <https://revistas.uexternado.edu.co/index.php/derest/article/view/5665>.

140 See the concerns of Cecilia Malmström when she talked about the need to implement a "rule of law" system, and not a "rule of lawyers". MALMSTRÖM, Cecilia. Concept Paper: Investment in TTIP And Beyond - The Path for Reform. European Commission, 2015.

141 BUTLER, Nicolette. Possible Improvements to The Framework of International Investment Arbitration. The Journal of World Investment \& Trade, vol. 14, issue 14, 2013, p. 632.

142 KOOPMANS, Tim. Globalisation of Administrative Law - the European Experience. In: GORDON, Anthony; AUBY, Jean-Bernard; MORISON, John; ZWART, Tom (eds.). Values in Global Administrative Law. London: Hart Publishing, p. 393-406, 2011. 
proposal would aim at the construction of a public court system with publicly appointed judges (in contrast with panels of private lawyers) composed of a first instance Tribunal and an Appeal Tribunal, always pointed prior to the emergence of the eventual dispute. This would ideally provide democratic grounds for the functioning of these courts and preserve the right to regulate of the states ${ }^{143}$.

But precisely, concerns raised against the ICS were essentially founded on the fact that it was meant to focus on administrative decisions and guarantee a State's "right to regulate"144. Detractors would argue that even if it solves legitimacy problems with regards to populist and protectionist demands, it would also highly increase regulatory associated risks for investors. Furthermore, "official" judges are necessarily to be financed by the Sates with vocation of permanence, raising costs in a scenario in which Stares are unwilling to provide financial resources ${ }^{145}$. Likewise, there is no evidence as to why judges are not going to be necessarily more impartial than arbitrators ${ }^{146}$.

There is, furthermore, an additional important issue, which is that judgements would set de facto precedence, something that does not happen in ISDS, thus establishing a new international official case-law to be followed. For that purpose, ICS mechanisms provide the creation of an appellate court as to unify possible disagreements in existing case-law. Even though this would give consistency to international judgements -remedying some of the inconsistency problems mentioned supra - it is not clear whether countries such as EU27 or the USA would necessarily welcome this circumstance, especially in an identity-based regression scenario ${ }^{147}$. Other traditional risks of creating an international court include delays for final judgements and increasing of the amount of cases to an unmanageable point ${ }^{148}$. Most of these characteristics however, although evidently negative, would in the end be the consequence of bringing international review mechanisms closer to domestic courts, with their benefits and disadvantages. Whether the balance is positive or whether the international community is ready for - or needs - this shift, is another question ${ }^{149}$.

143 KOETH, Wolfgang. Can the Investment Court System (ICS) save TTIP and CETA?. European Institute of Public Administration working paper, 2016/W/01, p. 5.

144 KOETH, Wolfgang. Can the Investment Court System (ICS) save TTIP and CETA?. European Institute of Public Administration working paper, 2016/W/01, p. 8.

145 MEKHENNET, Souad. Trump expands battle with WHO far beyond aid suspension. The Washington Post, $26^{\text {th }}$ April 2020.

146 GLEASON, Erin E. International Arbitral Appeals: What Are We So Afraid Of? Dispute Resolution Law Journal. vol. 7, 2007, p. 273-275.

147 KOETH, Wolfgang. Can the Investment Court System (ICS) save TTIP and CETA?. European Institute of Public Administration working paper 2016/W/01, p. 3.

148 GLEASON, Erin E. International Arbitral Appeals: What Are We So Afraid Of?. Dispute Resolution Law Journal. vol. 7, 2007, p. 273-275.

149 TAMS, Christian J. Is There a Need for an ICSID Appellate Structure? In: HOFMANN, Roald and TAMS, Christian (eds.) The International Convention For The Settlement Of Investment Disputes: Taking Stock After 40 Years, Nomos: Baden Baden, 2007. 
Judicial review for international agreements through ICS has already been applied by the EU-Vietnam Free Trade Agreement and the EU-Canada Comprehensive Economic and Trade Agreement (CETA), and more recently in the EU-Singapore Investment Protection Agreement and the EU-Mexico Trade Agreement ${ }^{150}$. In CETA, however, the expected effect of the creation of an ICS might be weakened in practice by the procedural access to the system, as CETA's provisions on dispute settlement still requires the claim to be brought up before the court against the infringing state, and not against an administrative decision. Therefore, if a supplier believes the CETA has been breached either by the contracting authority or the State, it has two options: (1) direct relief through the national claim's procedure ${ }^{151}$ or (2) indirect relief by suing the state itself before the ICS ${ }^{152}$. This procedure seems in practice to encourage national mechanisms for individual unfair treatments and the reservation of claims against the State (and therefore of international arbitration) to serious regulatory breaches ${ }^{153}$.

Other question for debate is the degree of autonomous enforceability of the court's decisions. The ISDS system does not apply automatically in light of the he lex arbitri principle. An exception to this rule is cases settled under the International Centre for State Investor Disputes (ICSID) of the World Bank, which are directly enforceable. In an ICS scenario, and according to some scholars, judgements would be de facto enforceable. ${ }^{154}$ But the mechanisms for direct enforceability vary on the supranational dispute settlement domain, and the EU preliminary ruling mechanism is a good example ${ }^{155}$. In the EU legal context, even if the CJEU case-law has binding effects and direct enforceability recognized by articles 280 and 290 of the TFEU, its decisions under preliminary ruling are not directly enforced in a traditional sense. The EU treaties and EU regulations are directly applicable in member states but enforced by domestic courts. It is common ground that whilst the European Court of Justice is the authoritative arbiter on the construction of Community law, it is not the primary enforcer thereof. Instead, the founding fathers of the Community opted for a system whereby enforcement of Community law

\footnotetext{
150 CHARRIS-BENEDETTI, Juan Pablo. The proposed Investment Court System: does it really solve the problems?. Revista Derecho del Estado, n. 42, p. 83-115, 2019. Available at: <https://revistas.uexternado.edu.co/ index.php/derest/article/view/5665>.

151 Article 14.3 of CETA's dispute settlement chapter specifies that recourse to the dispute settlement provisions of CETA are without prejudice to any action that Canada or the EU might bring under the GPA (which allows for access to the WTO dispute settlement procedure).

152 Article 8.23 of the CETA.

153 COLLINS, David A. Globalized Localism: Canada's Government Procurement Commitments under CETA. Journal of Transnational Dispute Management, n. 2, 2016.

154 KOETH, Wolfgang. Can the Investment Court System (ICS) save TTIP and CETA?. European Institute of Public Administration working paper, 2016/W/01.

155 The EU has been frequently claimed to represent a laboratory for globalisation in many ways. KEATING, Michael. Europe's Changing Political Landscape: Territorial Restructuring and New Forms of Government. In: BEAUMONT, Paul; LYONS, Carol; WALKER, Neil (eds). Convergence and Divergence in European Public Law. Oxford: Hart Publishing, 2002, p. 3.
} 
was left, in the first place, to the Member State courts ${ }^{156}$. Such a decentralized system of enforcement seems to be in line with the underlying nature of the proposed ICS and could serve as a possible line to follow for future amendments of the GPA ${ }^{157}$.

\section{THE TENSION BETWEEN THE GLOBALISATION PROCESS AND POPULIST MOVEMENTS}

As exposed, there is in general big enthusiasm within the academic doctrine as to the benefits of international trade for overall of the World population: it improves economic synergies and fosters both commercial and democratic developments ${ }^{158}$. So that when the legitimation of the treaties is distrusted, or when the enforcement mechanisms and review bodies are questioned, it is common to find proposals that imply a step forward as a way of legitimacy. If there is a problem with the inconsistency of judgements, let us make them courts-like judgements. If there is an atomization of international norms regarding foreign investment, let us "abandon the chaotic system of investment regulation, and strive towards the creation of a single, global overarching investment treaty"159. But if we take this approach to the legitimacy issues presented by international review mechanisms, we will be falling into a partly blind examination solely based on experts and enthusiasts, technology and passion, while excluding a broader spectrum of views ${ }^{160}$. Populism movements are a good reminder of the fact

\footnotetext{
156 HARLOW, Carol; RAWLINGS, Hunter R. Promoting Accountability in Multilevel Governance: A Network Approach. European Law Journal, n. C-06-02, 2007, p. 42. Available at: <http://www.mzes.uni-mannheim.de/ projekte/typo3/site/fileadmin/wp/pdf/egp-connex-C-06-02.pdf>.

157 BROBERG, Morten. The Preliminary Reference Procedure and Questions of International and National Law. Yearbook of European Law, vol. 28, n. 1, p. 362-389, 2009. Available at: < https://academic.oup.com/yel/article/28/1/362/1634246>.

158 TRIONFETTI, Federico. Public Procurement, Market Integration, and Income Inequalities. Review of International Economics, vol. 9, issue 1, p. 29-41, 2001. Available at: <https://onlinelibrary.wiley.com/doi/ epdf/10.1111/1467-9396.00261>; UTTLEY, Mathew R.H.; HARTLEY, Keith. Public Procurement in the Single European Market: Policy and Prospects. European Business Review, vol. 94, n. 2, 1994, p. 3-7. Available at: <https://www.emerald.com/insight/content/doi/10.1108/09555349410054132/full/html>; SMITH, Mitchell. State of Liberalization: Redefining the Public Sector in Integrated Europe. New York: State University of New York Press, 2005; CARBONI, Chiara; IOSSA, Elisabetta and MATTERA, Gianpiero. Barriers to Public Procurement: A Review and Recent Patterns in the EU. Working Paper IEFE - The Center for Research on Energy and Environmental, 92, 2017, p. 9; SCHOONER, Steven L.; YUKINS, Christopher R. Public Procurement: Focus on people, Value for Money and Systemic Integrity, Not Protectionism. In: BALDWIN, Richard and EVENETT, Simon (eds.). The Collapse of Global Trade, Murky Protectionism, and the Crisis: Recommendations for the G20. S.I: VoxEU.org Publication, 2017. Available at: <https://papers.ssrn.com/sol3/papers.cfm?abstract_id=1356170>.

159 BUTLER, Nicolette. Possible Improvements to The Framework of International Investment Arbitration. The Journal of World Investment \& Trade. vol. 14, 2013, p. 632; Malmström points to the same direction when she speaks about embedding the ICS into the context of a multilateral organization MALMSTRÖM, Cecilia. Concept Paper: Investment in TTIP And Beyond - The Path for Reform. European Commission, 2015.

160 CRAIG, Paul. Shared Administration and Networks: Global and EU Perspectives. In: GORDON, Anthony; AUBY, Jean-Bernard; MORISON, John; ZWART, Tom (eds.). Values in Global Administrative Law. London: Hart Publishing, p. 81-116, 2011.
} 
that the tension at the heart of modern constitutionalism requires an answer in more constructive terms ${ }^{161}$.

There is currently no efficient enforcement system at transatlantic level capable of tackling administrative decisions (non-regulatory) not expressly directed but implicitly oriented to favour national bidders. But as we have pointed out before, an artificial construction of institutional and legal enforcement, if it is not grounded on an abstract and, to some extent, irrational, sense of community, it would probably experience an eventual crisis of legitimacy ${ }^{162}$. The creation of permanent courts would imply a step forward that would require not just momentary or punctual acceptance by States of some terms and conditions, but long-term tolerance of a particular level of obedience to "higher" bodies that could lead to future restraints of sovereignty ${ }^{163}$. In the current situation, this seems somehow problematic, and it cannot be disregarded that, even if the concept has evolved, primary legitimacy is still mainly based in the $19^{\text {th }}$ Century idea of nation and sovereign State ${ }^{164}$.

On the other hand, review bodies, judicial activism and judicial dialogue has been demonstrated to be one of the key elements for the creation of a certain degree of togetherness - an embryonic demo - up on which other elements of harmonization can be taken ${ }^{165}$. However, the steps on this process must not obviate restraining elements such as the prevalence at origin of national identities ${ }^{166}$. Judiciary review might end up substituting at international level other dispute resolution mechanisms such as diplomacy or even arbitrary, but the process needs to avoid missteps.

Having said that, and according to what has been previously explained, the GPA possesses certain characteristics that make it a particularly wide and permanent tool as compared to other international economic norms. The use and acceptance of this norm seems to provide enough flexibility and vocation of permanence as to be consider something more than a treaty. As Yukins said, the GPA relies on participating countries

161 WALKER, Neil. Populism and Constitutional Tension. University of Edinburgh School of Law Research Paper, vol. 18, n. 18, 2018. Available at: <https://papers.ssrn.com/sol3/papers.cfm?abstract_id=3182359>; COX, Michael. The Rise of Populism and the Crisis of Globalisation. Irish Studies in International Affairs, vol. 28, p. 9-17, 2017. Available at: <http://eprints.Ise.ac.uk/86880/7/Cox_Rise\%20of\%20populism\%20published_2018. pdf $>$..

162 WALKER, Neil. Sovereignty and Beyond: The Double Edge of External Constitutionalism. Virginia Journal of International Law, vol. 57, issue 3, 2018, p. 799-820. Available at: <https://papers.ssrn.com/sol3/papers. cfm?abstract_id=3057407>.

163 WALKER, Neil. Sovereignty and Beyond: The Double Edge of External Constitutionalism. Virginia Journal of International Law, vol. 57, issue 3, 2018, p. 799-820. Available at: <https://papers.ssrn.com/sol3/papers. cfm?abstract_id=3057407>.

164 KYMLICKA, Will. Citizenship in an era of globalisation. In: SHAPIRO, lan; HACKER-GORDON, Casiano (eds.). Democracy's Edges. Cambridge: Cambridge University Press, p. 88-111, 1999.

165 AUBY, Jean-Bernard. Globalisation, Law and the State. Oxford: Hart Publishing, 2017, p. 92.

166 WALKER, Neil. The shaping of global law, Transnational Legal Theory, vol. 8, n. 3, p. 360-370, 2017. Available at: <https://www.tandfonline.com/doi/abs/10.1080/20414005.2017.1398510>. 
accepting the fundamental legitimacy of all of its parts, rather than opting out at will from particular agreements or provisions that are deemed disadvantageous at a particular point in time ${ }^{167}$.

Malmström has already pointed to the possibility of embedding the initially bi-lateral ICS into a multilateral organization ${ }^{168}$, and the GPA might seem a good start. Direct dispute settlement might not be necessary, and an indirect judicial dialogue based on the EU preliminary reference system might seem more adequate. After all, the possibility to claim possible breaches of the norm directly before national courts is already foreseen by the GPA ${ }^{169}$. Giving national courts a possibility to voluntarily seek clarification and engage in an international dialogue with the GPA provisions might indeed create grounds for greater accountability. As a construction based on "co-operative" sovereignty ${ }^{170}$, it would maintain national sovereignty and judicial enforceability, and at the same time it would ensure GPA presence and application in national interpretations, facilitating an indirect judicial review by the GPA permanent court in a sort of "shared Administration"171.

However, the main problem of creating an international court without direct enforcement powers and used by means of preliminary reference is that there might be difficulties in creating a convenient atmosphere among national judges to refer the issues to this court and enter into judicial dialogue with them as to engage into a decentralized enforcement mechanism ${ }^{172}$. The enforceability depends eventually on the reliance of national judges on the GPA as a clarifier or helping institution. In the EU, judicial dialogue and judicial activism has been traditionally referred as the jewel in the crown for EU integration. But it has been recently evidenced how institutional distrusts has emerged in the form of national courts not following the CJEU judgements -see the worries manifested by several scholars regarding the disregard of Weiss judgment reached by the German Constitutional Court (BVerfG) in its judgement published since

167 YUKINS, Christopher. Withdrawing the United States from the WTO Government Procurement Agreement (GPA): Assessing Potential Damage to the U.S. and Its Contracting Community. The Government Contractor, vol. 62, n. 6, 2020, p. 35. Available at: <https://scholarship.law.gwu.edu/cgi/viewcontent.cgi?article=2735\&context=faculty_publications $>$.

168 MALMSTRÖM, Cecilia. Concept Paper: Investment in TTIP And Beyond - The Path for Reform. European Commission, 2015.

169 DAVIES, Arwel. The Evolving GPA. Lessons of Experience and Prospects for the Future. In: GEORGOPULOS, Aris C; HOEKMAN, Bernard; MAVROIDIS, Petros C (eds.). The Internationalization of Government Procurement Regulation. Oxford Scholarship Online: 2017, p. 33.

170 AUBY, Jean-Bernard. Globalisation, Law and the State. Oxford: Hart Publishing, 2017, p. 105.

171 CRAIG, Paul. Shared Administration and Networks: Global and EU Perspectives. In: GORDON, Anthony; AUBY, Jean-Bernard; MORISON, John; ZWART, Tom (eds.). Values in Global Administrative Law. London: Hart Publishing, p. 81-116, 2011.

172 HÜBNER, Denise C. The decentralized enforcement of European law: national court decisions on EU directives with and without preliminary reference submissions. Journal of European Public Policy, vol. 25, issue 12, p. 1817-1834, 2018. Available at: <https://www.tandfonline.com/doi/abs/10.1080/13501763.2017.1376701>. 
May $5^{\text {th173}}$ - and the problems following the "uprising" do not seem of easy application due to political issues. This shows that the problem of such a system in times of international distrust is the potential difficulties with non-compliant countries, but also evidences the flexibility of EU judicial oversight, which does not require a lineal development and accepts some degree of inconsistencies ${ }^{174}$.

The implementation of a shared judicial review system between national systems and a permanent GPA interpreter would require this court, if we want it to be effective and respected, to be based on the strategic model of judiciary ${ }^{175}$, which assumes that judges carefully calculate the consequences of their choices ${ }^{176}$. In a context of identity reinforcement, this would require taking a rather deferring and permissive approach as to respect national particularities of application - in respect with strict principles of proportionality and subsidiarity ${ }^{177}$-, and in any case, only serious or clear breaches of the GPA might be rectified through harmonisation. Otherwise, national [legal] pride in particularly conflictive cases -one can easily imagine reluctance on the Supreme Court of the United States or the CJEU as to accept detailed scrutiny- is prone to re-emerge in form of populism. This would require, mutual recognition or reciproci$\mathrm{ty}^{178}$, as well as of a mechanism of a supple "dance of the courts", in which - as ironically referred to by Maximilian Steinbeis ${ }^{179}$ - potential conflicts are rather treated as elaborate competency issues between two courts who negotiate with each other at eye level ${ }^{180}$. After all, national courts would always have the right not to follow the WTO ruling when

173 BVerfG, Judgment of the Second Senate of 05 May 2020 - 2 BvR 859/15 -, paras. (1-237). See, as an example, the concerns manifested by SARMIENTO, Daniel. Requiem for judicial dialogue - The German Federal Constitutional Court's Judgement in the Weiss case and its European implications. EU Law Live, n16, 2020; and MARCO, Dani; MENDES, Joana, MENENDEZ, Agustín José, WILKINSON, Michael, SCHEPEL, Harm. At the End of the Law: A Moment of Truth for the Eurozone and the EU. VerfBlog. Retrieved in May $15^{\text {th }}, 2020$. Available at: <https:// verfassungsblog.de/at-the-end-of-the-law/>.

174 See the comments for the role of uncertainity in common law systems of MILLER, Russell A. In Praise of Uncertainty: The Constitutional Court's PSPP Decision. VerfBlog, June $4^{\text {th }}, 2020$. Available at: <https://verfassungsblog.de/in-praise-of-uncertainty/>.

175 ZWART, Tom. Would International Courts be Able to Fill the Accountability Gap at the Global Level?. In: GORDON, Anthony; AUBY, Jean-Bernard; MORISON, John; ZWART, Tom (eds.). Values in Global Administrative Law. London: Hart Publishing, p. 193-214, 2011.

176 EPSTEIN, Lee J.; KNIGHT, Jack. The Choices Justices Make. Washington DC: CQ Press, 1998, p. 128.

177 ORTEGA, Luis. Global Citizenship and Global Legitimacy. GORDON, Anthony; AUBY, Jean-Bernard; MORISON, John; ZWART, Tom (eds.). Values in Global Administrative Law. London: Hart Publishing, 2011, p. 251262; HERNÁNDEZ GONZÁLEZ, José Ignacio. El control de la Administración Pública a través del arbitraje internacional de inversiones. Barnés, Javier (coord.). Entre tribunales: libro homenaje a Pablo García Manzano. Madrid: Marcial Pons, 2018, p. 239-269, at 260.

178 PICARD, Gabriel B. Legality and legitimacy in global administrative law. e-Pública, vol. II, n. 3, p. 215-229, dez. 2015. Available at: <https://www.e-publica.pt/volumes/v2n3/pdf/Vol.2-N\%C2\%BA3-Art.14.pdf>.

179 STEINBEIS, Maximilian. We Super-Europeans. VerfBlog, May $8^{\text {th }}, 2020$. Available at: <https://verfassungsblog.de/we-super-europeans/>.

180 Regarding the non-hierarchical and non-automatic enforcement of WTO law in the EU, see BERGÉ, Jean-Sylvestre; HELLERINGER, Genevieve. Operating Law in a Global Context - Comparing, Combining and Prioritising. Oxford: Edward Elgar Publishing, 2017, p. 47. 
it has acted ultra vires or when it has not followed the basic principles of due process, as indeed already did the CJEU in Kadi ${ }^{181}$, or more recently the German BVerfG against the CJEU itself ${ }^{182}$.

Finally, the adoption of such a mechanism should not, nevertheless, imply the exclusion of the appellate body or the arbitration pursuant to articles 17 and 25 of the DSU (Dispute Settlement Understanding) and the WTO system as a valid dispute settlement system. In any case, the State-State settlement systems should be maintained as an ultima ratio, as it preserves the ad hoc and negotiated nature required to preserve national autonomy of choice. When the primary collective identity - the nation - comes to scene, dispute resolution must be based on equal-negotiated grounds, and arbitrary mechanisms seem quite convenient. This would give option to reluctance or honour-wounded States to undertake partial withdrawal and make unilateral expression of sovereign will for an ad hoc situation ${ }^{183}$.

In our view, such a system would present the correct characteristics as to strike a balance between sovereign self-assertion and sovereign self-binding on which the effective procurement system must be based ${ }^{184}$.

\section{CONCLUSIONS}

In the paper we have showed how populism and neo-protectionist tendencies are re-shaping the international sphere. Its functioning, clearly connected to group identity, jeopardize the primacy and applicability of the principle of non-discrimination on which global public procurement law is based. At the same time, current GPA review mechanisms fail to ensure administrative compliance - at contractual level with non-discrimination standards. The current complexity of international relations and international law requires a balance between enforced and voluntary-negotiated applicability of such provisions, and we find that the GPA review mechanisms fails to strike a balance between both approaches. On the one side, it does not reach effective oversight of administrative decisions potentially in breach of the GPA, and on the other, it does not respect current national claims to accept judgements over its sovereignty only coming from negotiated dispute-settlement mechanisms.

\footnotetext{
181 Cases C-584, 593 and 595/10 P, Commission and United Kingdom v. Yassin Abdullah Kadi (No 2) EU:C:2013:518.

182 See supra note 184.

183 WALKER, Neil. Sovereignty and Beyond: The Double Edge of External Constitutionalism. Virginia Journal of International Law, vol. 57, issue 3, 2018, p. 799-820. Available at: <https://papers.ssrn.com/sol3/papers. cfm?abstract_id=3057407>.

184 WALKER, Neil. The shaping of global law, Transnational Legal Theory, vol. 8, n. 3, 2017, p. 360-370. Available at: <https://www.tandfonline.com/doi/abs/10.1080/20414005.2017.1398510>; WALKER, Neil. Sovereignty and Beyond: The Double Edge of External Constitutionalism. Virginia Journal of International Law, vol. 57, issue 3, 2018, p. 799-820. Available at: <https://papers.ssrn.com/sol3/papers.cfm?abstract_id=3057407>.
} 
There is, in our opinion, a need for an international court on public procurement based on the GPA that can provide coherent legal interpretations on the content of the principles of public procurement and in particular with regard to non-discrimination. But at the same time, sovereign States must maintain its prevalence. For this, we suggest the creation of a real judicial dialogue with preliminary reference systems from national courts to the permanent GPA court, with a second and ultima ratio dispute settlement based on State-State which conserves the ad hoc and negotiated nature required to preserve national autonomy of choice. The weight and the initiative for institutional relation and the enforcement will remain at national level, maintaining besides a traditional bi-lateral arbitration-based mechanisms; and at the same time, the GPA Court would assemble greater influence through actual oversight national applicability of the GPA.

\section{REFERENCES}

ANDERSON, Robert D. and ARROWSMITH, Sue, The WTO regime on government procurement: past, present and future. In: ARROWSMITH, Sue and ANDERSON, Robert D. The WTO Regime on Government Procurement: Challenge and Reform. Cambridge: Cambridge University Press, 2011 , p. 3.

ANDERSON, Robert D.; MULLER, Ana C. The revised WTO Agreement on Government Procurement (GPA): Key Design Features and Significance for Global Trade and Development. Georgetown Journal of International Law, 48, p. 949-1008, 2017. Available at: < https://www.law.georgetown.edu/international-law-journal/wp-content/uploads/sites/21/2018/05/48-4-The-Revised-WTO-Agreement-on-Government-Procurement-GPA.pdf $>$.

ARROWSMITH, Sue. The Revised Agreement on Government Procurement: Changesto the Procedural Rules and Other Transparency Provisions. In: ARROWSMITH, Sue and ANDERSON, Robert D. The WTO Regime on Government Procurement: Challenge and Reform, Cambridge: Cambridge University Press, 2011.

AUBY, Jean-Bernard. Globalisation, Law and the State. 1st ed. Oxford: Hart Publishing, 2017

AYMERICH CANO, Carlos. La contratación pública en el TTIP. RVAP, 117, 2017, 19-41.

AZOULAI, Loïc and RITLENG, Dominique. Intégration européene et passions nsationales. Revue trimestrielle de droit européen, n. 4, 2018, pp.721.

BALDWIN, Richard E.; EVENETT, Simon J. (ed.). COVID-19 and Trade Policy: Why Turning Inward Won't Work. London: Centre for Economic Policy Research, 2020

BALDWIN, Richard; EVENETT, Simon. The collapse of global trade, murky protectionism and the crisis: Recommendations for the G20. Centre for Economic Policy Research (CEPR), 2009. 
BERGÉ, Jean-Sylvestre and HELLERINGER, Genevieve, Operating Law in a Global Context - Comparing, Combining and Prioritising. Oxford: Edward Elgar Publishing Ltd, 2017

BROBERG, Morten. The Preliminary Reference Procedure and Questions of International and National Law. Yearbook of European Law, vol. 28, n. 1, p. 362-389, 2009. Available at: < https:// academic.oup.com/yel/article/28/1/362/1634246>..

BUTLER, Nicolette. Possible Improvements to The Framework of International Investment Arbitration. The Journal of World Investment \& Trade, vol. 14, 2013, p. 632.

CARBONI, Chiara; IOSSA, Elisabetta and MATTERA, Gianpiero. Barriers to Public Procurement: A Review and Recent Patterns in the EU. Working Paper IEFE - The Center for Research on Energy and Environmental, 92, 2017.

CAREY, Sean. Undivided Loyalties: is national identity an Obstacle to European integration?. European Union Politics, vol. 3, issue 4, p. 387-413, 2002. Available at: < https://journals.sagepub. com/doi/10.1177/1465116502003004001>

CASSESSE, Sabino. Il diritto globale. Torino: Einaudi, 2009.

CASTELLS, Manuel. The Power of Identity. $2^{\text {nd }}$ ed. Malden: Wiley-Blackwell, 1997.

KUTLINA-DIMITROVA, Zornitsa. Why public procurement openness is more important now than ever. CEPR Policy Portal, 16 april 2020. Available at: <https://voxeu.org/article/ why-public-procurement-openness-more-important-now-ever>.

CERNY, Philip G. Globalization and the End of Democracy. European Journal of Political Research, vol. 36, n. 1, 1999.

CHARRIS-BENEDETTI, Juan Pablo. The proposed Investment Court System: does it really solve the problems?. Revista Derecho del Estado, 42, 2.

CHENEVAL, Francis and NICOLAIDIS, Kalypso. The social construction of demoicracy in the European Union. European Journal of Political Theory, vol. 16, issue 2, p. 235-260, 2017. Available at: < https://journals.sagepub.com/doi/abs/10.1177/1474885116654696>.

CLERC, Evelyne. La mondialisation des marchés publics. BATSELÉ, Didier et al. (eds.), Les marchés publics à l'aube du XXle siècle, Bruxelles: Bruylant, p. 141-194, 2000.

COLLINS, David A. Globalized Localism: Canada's Government Procurement Commitments under CETA. Journal of Transnational Dispute Management, n. 2, 2016.

CONSTANTINESCU, Cristina; MATTOO, Aaditya; RUTA, Michele. The Global Trade Slowdown: Cyclical or Structural?. International Monetary Found, vol. 15, n. 6, Jan. 2015. Available at: < https:// www.imf.org/external/pubs/ft/wp/2015/wp1506.pdf >. 
CORVAGLIA, Maria Anna. TTIP Negotiations and Public Procurement: A Federalist Approach. Journal World Investment and Trade, vol. 19, n. 3, p. 392-414, 2017. Available at: < https://papers. ssrn.com/sol3/papers.cfm?abstract_id=2958136>.

COTTIER, Thomas. Trade Policy in the Age of Populism: Why the New Bilateralism Will Not Work. Brexit: The International Legal Implications, Paper $n$ 12, 2018.

COX, Michael. The Rise of Populism and the Crisis of Globalisation. Irish Studies in International Affairs, vol. 28, p. 9-17, 2017. Available at: < http://eprints.Ise.ac.uk/86880/7/Cox_Rise\%20of\%20 populism\%20published_2018.pdf>..

CRAIG, Paul. Shared Administration and Networks: Global and EU Perspectives. In: GORDON, Anthony; AUBY, Jean-Bernard; MORISON, John; ZWART, Tom (eds.). Values in Global Administrative Law. London: Hart Publishing, p. 81-116, 2011.

CRAIG, P. UK, EU and Global Administrative Law: Foundations and Challenges. Cambridge: Cambridge University Press, 2015.

CRAIG, Paul. Brexit, A Drama: The Interregnum. Yearbook of European Law, vol. 36, n. 1, p. 3-45, 2017. Available at: <https://academic.oup.com/yel/article/doi/10.1093/yel/yex005/4562542>.

DALY, Paul. Reprendre le contrôle: ennuis et ironies (The Ironies of 'Taking Back Control'). Legal Studies Research Paper Series, n. 38, 2018. Available at: <https://papers.ssrn.com/sol3/papers. cfm?abstract_id=3162560>.

DAMASIO, Antonio, R. Self Comes to Mind: Constructing the Conscious Brain. London: Pantheon, 2010.

DAVIES, Arwel. The Evolving GPA. Lessons of Experience and Prospects for the Future. In: GEORGOPULOS, Aris C; HOEKMAN, Bernard; MAVROIDIS, Petros C. (eds.). The Internationalization of Government Procurement Regulation. Oxford Scholarship Online: March 2017, p. 23-55.

DAWAR, Kamala. The Government Procurement Agreement, the Most-Favored Nation Principle, and Regional Trade Agreements. In: GEORGOPULOS, Aris C; HOEKMAN, Bernard and MAVROIDIS, Petros C. The Internationalization of Government Procurement Regulation. Oxford Scholarship Online: March 2017, p. 113.

DELMAS MARTY, Mireille. Trois défis pour un droit mondial. Paris: Le Seuil, 1997.

DEZSŐ ZIEGLER, Tamás. TTIP and Its Public Criticism: Anti-Globalist Populism versus Valid Dangers. Studies in International Economics, 2016, vol. 2, n. 2, p. 19-51. Available at: < https://papers.ssrn.com/sol3/papers.cfm?abstract_id=2930039>.

DÍAZ BRAVO, Enrique and RODRÍGUEZ LETELIER, Aníbal. Contratos administrativos en Chile. Santiago de Chile, RIL Editores, 2016.

DISDIER, Anne-Célia; FONTAGNÉ, Lionel; ENXHI, Tresa. Public Procurement- Related Protection: Insights from the Global Trade Alert Database. European Commission Technical Report 2017. 
DUFFY-MEUNIER, Aurélie. Réflexions de nature constitutionnelle sur la loi sur le retrait du Royaume-Uni de l'Union européenne, I'European Union (Withdrawal) Act 2018. Revue trimestrielle de droit européen, vol. 64, n. 4, 2018, p. 759-781.

EPSTEIN, Lee J. and KNIGHT, Jack. The Choices Justices Make. Washington DC: CQ Press, 1998.

ERIXON, Fredrik; SALLY, Razeen. Trade, Globalisation And Emerging Protectionism Since The Crisis. ECIPE Working Paper, n. 2, p. 2-20, 2010. Available at: <https://www.econstor.eu/bitstream/10419/174841/1/ecipe-wp-2010-02.pdf>.

EUROPEAN COMMISSION. Report from the Commission de réflexion pour la prévention des conflits d'intérêts dans La Vie Publish. Pour une nouvelle déontologie De la vie Publique. Presented to President Of the French Republic on 26 January 2011, p. 15. Available at: <https:// www.hatvp.fr/wordpress/wp-content/uploads/2016/02/Rapport-Commission-Sauve.pdf>

FERRAJOLI, Luigi. Poderes Salvajes: la crisis de la democracia constitucional. Madrid:Trotta, 2013.

FRIEDEN, Jeffry A. The Backlash Against Globalization and the Future of the International Economic Order. PATRICK, Diamond (ed.) The crisis of globalization: democracy, capitalism and inequality in the twenty-first century. London and New York: IB Tauris, 2019, p. 133.

FUKUYAMA, Francis. The end of History and the Last Man. $1^{\text {st }}$ ed. London: Penguin, 2012.

GAMBLE, Andrew. Globalization and the New Populism. PATRICK, Diamond (ed.) The crisis of globalization: democracy, capitalism and inequality in the twenty-first century. London and New York: IB Tauris, 2019, pp. 90.

GERAPETRITIS, George. Affirmative Action: A New Challenge for Equality. In: GORDON, Anthony; AUBY, Jean-Bernard; MORISON, John; ZWART, Tom (eds.). Values in Global Administrative Law. London: Hart Publishing, p. 263-296, 2011.

GIDRON, Noam; HALL, Peter A. Populism as a Problem of Social Integration. Comparative Political Studies, vol. 53, n. 7, p. 1027-1059. Available at: <https://journals.sagepub.com/doi/ abs/10.1177/0010414019879947>.

GLEASON, Erin E. International Arbitral Appeals: What Are We So Afraid Of? Dispute Resolution Law Journal, vol. 7, 2007, p. 273-275.

GOLDMAN, David. Historial Aspects of Globalisation and Law. In: DAUVERGNE, Catherine (ed). Jurisprudence for an Interconnected Globe. Aldershot: Ashgate, 2003.

GORDON, Daniel I. GPA Institutional Provisions: Domestic Review Procedures \& WTO Dispute Settlement. Symposium on the revised WTO agreement on government procurement. Geneva, September 2015.

GÓRSKI, Jędrzej. Public Procurement in 21 st Century: Balancing Liberalisation, Social Values and Protectionism. Thesis Submitted in Partial Fulfilment of the Requirements for the Degree of Doctor of Philosophy in Laws, The Chinese University of Hong Kong July 2016, p. 36 
GRUSZCZYNSKI, Lukasz. The COVID-19 Pandemic and International Trade: Temporary Turbulence or Paradigm Shift?. European Journal of Risk Regulation, vol. 11, n. 2, p. 337-342, 2020. Available at: <https://papers.ssrn.com/sol3/papers.cfm?abstract_id=3669017>.

HAMADA, Koichi. A Better Approach to Globalization. Yale Global Online, 2018. Available at: < https://yaleglobal.yale.edu/content/better-approach-globalization>.

HAMADA, Koichi. Why we need globalization. The Japan Times, 2018. Available at: <https://www. japantimes.co.jp/opinion/2018/05/03/commentary/japan-commentary/why-we-need-globalization/\#.XJOTxi3FTOS>.

HARLOW, Carol; RAWLINGS, Hunter R. Promoting Accountability in Multilevel Governance: A Network Approach. European Law Journal, n. C-06-02, p. 542-652, 2007. Available at: <http://www. mzes.uni-mannheim.de/projekte/typo3/site/fileadmin/wp/pdf/egp-connex-C-06-02.pdf>.

HAYES, Eric. TTIP: transatlantic free trade at last?. Global Affairs, vol. 1, n. 2, p. 113-120, 2015. Available at: <https://www.tandfonline.com/doi/abs/10.1080/23340460.2015.1012914>.

HERNÁNDEZ GONZÁLEZ, José Ignacio. Las prerrogativas de la administración en los contratos de las administraciones públicas en Iberoamérica. In: RODRÍGUEZ-ARANA, Jaime; MORANDINI, Federico and FERNÁNDEZ CARBALLAL, Almudena. Contrataciones públicas en el marco de los derechos sociales fundamentales. Madrid : Instituto Nacional de Administración Pública, 2017, pp. 67-100.

HERNÁNDEZ GONZÁLEZ, José Ignacio. El control de la Administración Pública a través del arbitraje internacional de inversiones. Barnés, Javier. (coord.) Entre tribunales: libro homenaje a Pablo García Manzano. Madrid: Cuatrecasas - Marcial Pons, 2018, pp. 239-269.

HERNÁNDEZ GONZÁLEZ, José Ignacio. El contrato administrativo en el derecho administrativo global: Una perspectiva Iberoamericana. In: ALCARAZ, Hubert and VERGARA BLANCO, Alejandro. Itinerario latinoamericano del derecho público francés. Tirant Lo Blanch, 2019, pp. 367-382.

HOEKMAN, Bernard; FIORINI, Matteo and YILDIRIM, 5 COVID-19: Export controls and international cooperation. In: BALDWIN, Richard E. and EVENETT, Simon J. COVID-19 and Trade Policy: Why Turning Inward Won't Work. London: Centre for Economic Policy Research, pp. 63-76.

HORVATH, Gunter J. and BERZERO, Roberta. Arbitrator and Counsel: The Double-Hat Dilemma. Transnational Dispute Management (TDM). 2017.

HUDSON, Josh, DAWSEY, J.; MEKHENNET, Souad. Trump expands battle with WHO far beyond aid suspension. The Washington Post, $26^{\text {th }}$ April 2020.

HÜBNER, Denise C. The decentralized enforcement of European law: national court decisions on EU directives with and without preliminary reference submissions. Journal of European Public Policy, vol. 25, issue 12, 2018, p. 1817-1834. Available at: <https://www.tandfonline.com/doi/abs /10.1080/13501763.2017.1376701>. 
INNERARITY, Daniel. El nuevo espacio público. Madrid: Espasa Libros, 2006.

KALDOR, Mary. Nationalism and Globalisation. Nations and Nationalism, vol. 10, n. 1-2, 2004, p. 161-177, Available at: <https://onlinelibrary.wiley.com/doi/10.1111/j.1354-5078.2004.00161.x> KOETH, Wolfgang. Can the Investment Court System (ICS) save TTIP and CETA?. European Institute of Public Administration working paper, 2016/W/01

KEATING, Michael Europe's Changing Political Landscape:Territorial Restructuring and New Forms of Government. In: BEAUMONT, Paul; LYONS, Carol and WALKER, Neil (eds), Convergence and Divergence in European Public Law. Oxford: Hart Publishing, 2002.

KINGSBURY, Benedict, KRISCH, Nico; STEWART, Richard, The Emergence of Global Administrative Law. Law and Contemporary Problems, vol. 68, n. 15, 2005.

KOETH, Wolfgang. Can the Investment Court System (ICS) save TTIP and CETA?. European Institute of Public Administration working paper, 2016/W/01.

KOOPMANS, Tim. Globalisation of Administrative Law-the European Experience. In: GORDON, Anthony; AUBY, Jean-Bernard; MORISON, John; ZWART, Tom (eds.). Values in Global Administrative Law. London: Hart Publishing, p. 393-406, 2011.

KUTLINA-DIMITROVA, Zornitsa. Government Procurement: Data, Trends And Protectionist Tendencies. DG Trade, issue 3, Sep. 2018. Available at: < https://trade.ec.europa.eu/doclib/docs/2018/ september/tradoc_157319.pdf>.

KUTLINA-DIMITROVA, Zornitsa; LAKATOS, Csilla. The Global Costs of Protectionism. World Bank Policy Research Working Paper, Washington, n. 8277, Dec. 2017. Available at: <http://documents1.worldbank.org/curated/en/962781513281198572/pdf/WPS8277.pdf>.

KYMLICKA, Will. Citizenship in an era of globalisation. In SHAPIRO, lan and HACKER-GORDON, Casiano (eds), Democracy's Edges. Cambridge: Cambridge University Press, 1999, p. 88-111.

LAIRD, Ian; ASKEW, Rebecca. Finality versus Consistency: Does Investor State Arbitration Need an Appellate System?. The Journal of Appellate Practice and Process, vol.7, issue 2, 2005, p. 299. Available at: <https://lawrepository.ualr.edu/cgi/viewcontent. cgi?article $=1328 \&$ context $=$ appellatepracticeprocess $>$.

LINARELLI, John. Global procurement law in times of crisis: new buy American policies and options in the WTO system. In: ARROWSMITH, S. and ANDERSON, R.D. The WTO Regime on Government Procurement: Challenge and Reform. Cambridge: Cambridge University Press, 2011, pp. 773-802.

MAIR, Peter. The europeanization dimensión. Journal of European Public Policy, vol. 11, issue 2, p. 337-348, 2004.

MALMSTRÖM, Cecilia. Concept Paper: Investment in TTIP And Beyond - The Path for Reform. European Commission, 2015. 
MARCO, Dani; MENDES, Joana, MENENDEZ, Agustín José, WILKINSON, Michael, SCHEPEL, Harm. At the End of the Law: A Moment of Truth for the Eurozone and the EU. VerfBlog. Retrieved in $15^{\text {th }}, 2020$. Available at: <https://verfassungsblog.de/at-the-end-of-the-law/>.

MEKHENNET, Souad. Trump expands battle with WHO far beyond aid suspension. The Washington Post, $26^{\text {th }}$ April 2020

MILLER, Russell A. In Praise of Uncertainty: The Constitutional Court's PSPP Decision. VerfBlog. Retrieved in June $4^{\text {th }}, 2020$. Available at: <https://verfassungsblog.de/in-praise-of-uncertainty/>.

MIRANZO DÍAZ, Javier. Causas y efectos de la corrupción en las sociedades democráticas. Revista de la Escuela Jacobea de Posgrado, n. 14, p. 1-26, jun. 2018. Available at: <https://www.jacobea. edu.mx/revista/numero14.php>

MIRANZO DÍAZ, Javier. Hacia la configuración de una estrategia eficiente de integridad en la contratación pública. Madrid: Marcial Pons, 2020.

MORENO MOLINA, José Antonio. Derecho Global de la Contratación Pública. Ciudad de México: Ubijus, 2011.

MORENO MOLINA, José Antonio. El nuevo Derecho de la Contratación Pública de la Unión Europea: directivas 4.0. Oxford: Chartridge Books Oxford, 2015.

MORISON, John; GORDON, Anthony. The Place of Public Interest. In: GORDON, Anthony; AUBY, Jean-Bernard; MORISON, John; ZWART, Tom (eds.). Values in Global Administrative Law. London: Hart Publishing, p. 215-238, 2011.

MPEERA NTAYI, Joseph; NGOBOKA, Pascal; SABIITI KAKOOZA, Cornelia. Moral Schemas and Corruption in Ugandan Public Procurement. Journal of Business Ethics, vol. 112, issue 3, p. 417-436, 2013. Available at: <https://link.springer.com/article/10.1007/s10551-012-1269-7>.

ORTEGA, Luis. Global Citizenship and Global Legitimacy. GORDON, Anthony; AUBY, Jean-Bernard; MORISON, John; ZWART, Tom (eds.). Values in Global Administrative Law. London: Hart Publishing, p. 251-262, 2011.

PATRICK, Diamond. The Great Globalization Disruption: Democracy, Capitalism and Inequality in the Industrial World. PATRICK, Diamond (ed.) The crisis of globalization: democracy, capitalism and inequality in the twenty-first century. London: IB Tauris, 2019, p. 31.

PICARD, Gabriel B. Legality and legitimacy in global administrative law. e-Pública, vol. II, n. 3, p. 215-229, dez. 2015. Available at: <https://www.e-publica.pt/volumes/v2n3/pdf/Vol.2-N\%C2\%BA3-Art.14.pdf>.

PÎRVU, Daniela; BÂLDAN, Cristina. Access to the EU Public Procurement Market: Are There Disparities Based on the Origin of Economic Operators?. Journal of Economic Issues, vol. XLVII, n. 3, p. 765-780, 2013. Available at: <https://www.tandfonline.com/doi/ref/10.2753/ JEI0021-3624470309?scroll=top>. 
RODI, Patricia. Populist Political Communication Going Mainstream? The Influence of Populist Parties on Centre-Left Parties in Western Europe. PATRICK, Diamond (ed.) The crisis of globalization: democracy, capitalism and inequality in the twenty-first century. London and New York: IB Tauris, 2019, p. 167.

RODRÍGUEZ-ARANA MUÑOZ, Jaime. La Directiva Europea de Contratación Pública y la lucha contra la corrupción. Revista de Direito Econômico e Socioambiental, Curitiba, v. 8, n. 1, p. 24-56, jan/abr. 2017.

RODRÍGUEZ-ARANA MUÑOZ, Jaime. The principles of the global law of public procurement. A\&C - Revista de Direito Administrativo \& Constitucional, Belo Horizonte, ano 16, n. 65, p. 13-37, jul./set. 2016.

SARMIENTO, Daniel. Requiem for judicial dialogue - The German Federal Constitutional Court's Judgement in the Weiss case and its European implications. EU Law Live, n16, 2020.

SCHMIDT-AßMANN, Eberhard. Principles of an International Order of Information. In: GORDON, Anthony; AUBY, Jean-Bernard; MORISON, John; ZWART, Tom (eds.). Values in Global Administrative Law. London: Hart Publishing, p. 117-124, 2011.

SCHOENI, Daniel E. On the Non-tariff Barriers Obstructing Free Trade in the Transatlantic Defense Procurement Market. In: RACCA, Gabriela, and YUKINS, Christopher. Joint Public Procurement and Innovation: Lessons Across Borders. Brussels: Brulyant, p. 419-470, 2019.

SCHOLTE, Jan Aart. Global Civil Society. In: WOODS, Ngaire (ed), The Political Economy of Globalization. London: Macmillan, p. 173-201, 2000.

SCHOTT, Jeffrey J. and JUNG, Euijin. The WTO's Existential Crisis: How to Salvage Its Ability to Settle Trade Disputes. S.L. Peterson Institute for International Economics, 2019.

SCHOONER, Steven L. and YUKINS, Christopher R. Public Procurement: Focus on people, Value for Money and Systemic Integrity, Not Protectionism. In: BALDWIN, Richard and EVENETT, Simon (eds.). The Collapse of Global Trade, Murky Protectionism, and the Crisis: Recommendations for the G20. S.I.: VoxEU.org Publication, 2017. Available at: < https://papers.ssrn.com/sol3/papers. cfm?abstract_id=1356170>.

SCHWARTZ, Joshua I. Procurement in times of crisis: lessons from US government procurement in three episodes of crisis in the twenty-first century. In: ARROWSMITH, S. and ANDERSON, Robert D. The WTO Regime on Government Procurement: Challenge and Reform. Cambridge: Cambridge University Press, 2011. pp. 773-802.

SMITH, Mitchell. State of Liberalization: Redefining the Public Sector in Integrated Europe. New York: State University of New York Press, 2005.

SOLOVEICIK, Deividas and SIMANSKIS, Karolis. The Evolving Concept of «Conflict of Interest» in the EU Public Procurement Law. European Procurement \& Public Private Partnership Law 
Review (EPPPL), vol. 12, issue 2, p. 112-131, 2017. Available at: <https://epppl.lexxion.eu/article/ EPPPL/2017/2/6.

STEINBEIS, Maximilian. We Super-Europeans, VerfBlog. Retrieved May $8^{\text {th }}, 2020$. Available in: https://verfassungsblog.de/we-super-europeans/

TAGIURI, Giacomo. EU law and national belonging: Appeasing insiders while Resisting Nationalisms. Revue trimestrielle de droit européen, n. 4, Dalloz, 2018, p. 743. Available at: <https:// www.researchgate.net/publication/342833586_The_tension_between_global_public_procurement_law_and_nationalistpopulist_tendencies_proposals_for_reform $>$.

TAMS, Christian J. Is There a Need for an ICSID Appellate Structure? In: Hofmann, Roald and Tams, Christian (eds.) The International Convention For The Settlement Of Investment Disputes: Taking Stock After 40 Years, Nomos: Baden Baden, 2007.

TRIONFETTI, Federico. Public Procurement, Market Integration, and Income Inequalities. Review of International Economics, vol. 9, issue 1, p. 29-41, 2001. Available at: <https://onlinelibrary. wiley.com/doi/epdf/10.1111/1467-9396.00261>.

TRIPATHI, Rajeshwar. Concept of Global Administrative Law: An Overview. India Quarterly, vol. 67, issue 4, p. 355-372, 2011. Available at: <https://journals.sagepub.com/doi/abs/10.1177/0974 $92841106700405>$.

TSOUKALIS, Loukas. Brexit and Globalization: Collateral Damage or an Accident Waiting to Happen?. D. PATRICK, Diamond (ed.) The crisis of globalization: democracy, capitalism and inequality in the twenty-first century. London and New York: IB Tauris, 2019.

UTTLEY, Mathew R.H.; HARTLEY, Keith. Public Procurement in the Single European Market: Policy and Prospects. European Business Review, vol. 94, n. 2, p. 3-7, 1944. Available at: <https://www. emerald.com/insight/content/doi/10.1108/09555349410054132/full/html>.

WALKER, Neil. The shaping of global law, Transnational Legal Theory, vol. 8, n. 3, p. 360-370, 2017. Available at: <https://www.tandfonline.com/doi/abs/10.1080/20414005.2017.1398510>

WALKER, Neil. Populism and Constitutional Tension. University of Edinburgh School of Law Research Paper, vol. 18, n. 18, 2018. Available at: <https://papers.ssrn.com/sol3/papers. cfm?abstract_id=3182359>.

WALKER, Neil. Sovereignty and Beyond: The Double Edge of External Constitutionalism. Virginia Journal of International Law, vol. 57, issue 3, p. 799-820, 2018. Available at: <https://papers.ssrn. com/sol3/papers.cfm?abstract_id=3057407>.

WOLFE, Robert. Exposing governments swimming naked in the COVID-19 crisis with trade policy transparency (and why WTO reform matters more than ever). In: BALDWIN, Richard E.; EVENETT, Simon J. COVID-19 and Trade Policy: Why Turning Inward Won't Work. London: Centre for Economic Policy Research, p. 165-178, 2020. 
WOOLCOCK, Steve and HEILMAN GRIER, Jean. Public Procurement in the Transatlantic Trade and Investment Partnership Negotiations. Paper No. 2 in the CEPS-CTR project "TTIP in the Balance" and CEPS Special Report No. 100, 2015. Available at: <https://www.ceps.eu/system/files/SR100PublicProcurementandTTIP.pdf>.

YUKINS, Christopher. Breaking The Impasse In The Transatlantic Trade And Investment Partnership (TTIP) Negotiations: Rethinking Priorities In Procurement. The Government Contractor, vol. 56, n. 27, 2014. Available at: <https://papers.ssrn.com/sol3/papers.cfm?abstract_id=2471653>.

YUKINS, Christopher R. The European Procurement Directives and The Transatlantic Trade \& Investment Partnership (TTIP): Advancing U.S. - European Trade and Cooperation in Procurement. GWU Law School Public Law Research Paper, n. 2014-15, 2014. Available at: <https://papers. ssrn.com/sol3/papers.cfm?abstract_id=2433219>.

YUKINS, Christopher. US Government Contracting in the Context of Global Public Procurement. In: GEORGOPULOS, Aris C; HOEKMAN, Bernard; MAVROIDIS, Petros C. The Internationalization of Government Procurement Regulation. Oxford Scholarship Online: p. 265-287, 2017.

YUKINS, Christopher. Withdrawing the United States from the WTO Government Procurement Agreement (GPA): Assessing Potential Damage to the U.S. and Its Contracting Community. The Government Contractor, vol. 62, n. 6, 2020. Available at: <https://scholarship.law.gwu.edu/cgi/ viewcontent.cgi?article $=2735 \&$ context=faculty_publications $>$

ZWART, Tom. Would International Courts be Able to Fill the Accountability Gap at the Global Level?. In: GORDON, Anthony; AUBY, Jean-Bernard; MORISON, John; ZWART, Tom (eds.). Values in Global Administrative Law. London: Hart Publishing, p. 193-214, 2011. 